\title{
Attitudes towards LGBT individuals after Bostock v. Clayton County: Evidence from a quasi-experiment
}

\author{
Jack Thompson*
}

August 20, 2021

\begin{abstract}
Do United States Supreme Court decisions on LGBT rights shape attitudes towards LGBT individuals among the mass public? In this paper, I conduct an empirical test of the effect of quasi-random exposure to the announcment of Bostock v. Clayton County a landmark case which held that that an employer who fires their employee because of their sexual orientation or gender identity violates Section VII of the 1964 Civil Rights Act - on favorability towards LGBT individuals. Relying on data from Phase 2 of the Democracy Fund/UCLA Nationscape survey, I find that quasi-random exposure to the announcement of Bostock engendered increases in favorability towards LGBT individuals among the wider American public. Subgroup analyses also indicate that the largest increases in favorability were among Democratic partisans and the religiously unaffiliated, while minimal changes in favorability were detected among those who are among the most likely to oppose LGBT rights, including Republicans and Evangelical Protestants. The findings speak to the validity of the legitimacy model and highlight the limitations of the backlash model in the post-Obergefell era of public opinion towards LGBT rights.
\end{abstract}

Keywords: Supreme Court, LGBT, Bostock v. Clayton County

*Postdoctoral Research Fellow, University of Exeter. Email: j.thompson4@exeter.ac.uk 


\section{Introduction}

On June 15, 2020, the Supreme Court held in a landmark civil rights case - Bostock $v$. Clayton County 1 - that an employer who fires their employee because of their sexual orientation or gender identity violates Section VII of the 1964 Civil Rights Act. Following landmark cases such as Lawrence v. Texas (2003), and Obergefell v. Hodges (2015), Bostock was widely seen as another watershed moment in furthe enshrining LGBT rights (Liptak 2020. Millhiser 2020). In addition to understanding how policy implementation leads to greater social benefits and higher rates of inclusion for LGBT individuals in US society (Flores et al.2020), scholars have analyzed how Supreme Court decisions on LGBT rights shape attitudes towards LGBT individuals among the mass public (Aksoy, Carpenter, Haas \& Tran 2020, Keck 2009, Stoutenborough, Haider-Markel \& Allen 2006). However, scholars interested in the effects of policy implementation on mass attitudes have not examined whether policy gains on protections from discrimination in employment may lead to more favorable estimations of LGBT individuals. In this paper, I therefore test the possibility that Bostock shaped public attitudes towards LGBT individuals with a novel research design and the use of timely data.

Models examining the effects of Supreme Court decisions on mass opinion point to a number of possible effects, including backlash, polarization, legitimacy, and consensus. In this paper, I ground my theoretical expectations concerning attitudes towards LGBT individuals among the larger public within the legitimacy model, positing that exposure to the announcement of Bostock led to increased favorable estimations towards LGBT individuals (H1). Pre-Obergefell, scholars found evidence of a backlash effect (i.e., SCOTUS decisions engendering greater homonegative attitudes) in mass opinion towards LGBT individuals (Klarman 2012). Post-Obergefell, however, many studies found that the normshaping role of same-sex marriage reform decision led to increases in favorable estimations towards LGBT individuals (Flores \& Barclay|2016, Kazyak \& Stange|2018, Tankard \&

\footnotetext{
${ }^{1}$ Hereinafter Bostock
} 
Paluck 2017), thus lending weight to the theoretical expectations of the legitimacy model.

Despite the clear increases in public support for LGBT individuals and pro-LGBT policies over time (see Figures 1-2), there is nonetheless also reason to expect a potential for backlash among particular sections of the American public in response to Bostock. In the post-Obergefell era, the religious right have become increasing adept at mobilizing in opposition to LGBT rights, including the right for individuals to use the bathroom that corresponds to their gender identity, and the right of businesses to refuse service to LGBT persons on the grounds of "religious liberty" (Ayoub \& Page 2020). As such, while studies cast doubt on the robustness of the backlash model as a means of understanding the effects of Supreme Court decisions on public attitudes towards LGBT individuals post-Obergefell, there is a possibility for backlash among religious affiliates, and especially Evangelical Christians (H2). Moreover, given the extent of sociopolitical sorting and polarization (Levendusky 2009), there is reason to expect that there will asymmetric effects to exposure to news about the announcement of Bostock when individuals are contrasted on partisanship (H3).

Empirically, I present quasi-experimental evidence from the Phase 2 of the 2019-2020 Democracy Fund/UCLA Nationscape survey. Exploiting as good as random exposure to the widely reported news stories regarding the announcement of Bostock, I rely on the "unexpected event during survey fieldwork framework (Muñoz et al. 2020) to provide evidence that quasi-random exposure led to substantive changes in public favorability towards LGBT individuals.

This paper contributes to the extant scholarship in three important ways. First, it provides additional evidence that mass attitudes towards LGBT individuals move in the direction of increasing favorability after exposure to Supreme Court decisions on LGBT rights. Second, while the scholarship has largely focussed on the impact of same-sex marriage reform on favorability towards LGBT individuals, the findings demonstrate that these effects are not limited to exposure to the announcement of Obergefell. This find- 
ing is important because it increases the generalizability of the legitimacy model as a means for understanding the impact of policy implementation on mass opinion towards LGBT rights (Flores \& Barclay 2016). Third, it demonstrates the limitations of the backlash model despite the increased mobilization of the religious right in opposition to LGBT rights.

The structure of the paper proceeds as follows. I begin by examining trends in public opinion towards LGBT individuals. Drawing on the extant scholarship on Supreme Court decisions and their effects on mass opinion, I then outline three testable hypotheses concerning the effects of quasi-random exposure to the announcement of Bostock on mass attitudes towards LGBT individuals. ${ }^{2}$ After delineating my hypotheses, I turn to data and methods, outlining my quasi-experimental research design consistent with the "unexpected event during survey fieldwork" framework outlined by (Muñoz et al. 2020). I then present results and conclude by reflecting on the significance of the findings, including their implications for understanding which models of public opinion are the most relevant for gauging the impact of Supreme Court decisions on public opinion towards LGBT individuals in the post-Obergefell era.

\section{LGBT Individuals in US Public Opinion}

In the mid-Twentieth Century, McCarthy-era moral panics such as the lavender scare led to the mass dismissal of gays and lesbians from a variety of government services (Johnson 2009). The federal government's response to a visible Queer community led to the institutionalized persecution of those who openly identified as LGBT. These developments did little to foster contexts where individuals could openly identify as sexual minorities without incurring a significant cost to their reputation and standing in American public

\footnotetext{
${ }^{2}$ The wording of the dependent measure in the Nationscape survey is such that I am only able to gauge favorability towards gays and lesbains. The wording of this item is similar to those that have been included in the ANES since 1984. Nonetheless, it is important to be aware that the wider community also include those who are trans, Queer, intersex, and asexual (LGBTQIA).
} 
life. From the late Sixties onwards, however, the gay liberation movement encouraged lesbians and gay men to counter societal shame with gay pride. Though gay liberation favored radical direct action as a response to homophobia (Kissack 1995), the most basic form of activism was an emphasis on being openly Queer, including coming out to friends, family, and work colleagues (Jay \& Young[1992). As the personal and reputational costs of being openly LGBT have decreased over time, the percentage of Americans who personally know someone who is LGBT, and who reside in areas of the US with a greater density of LGBT-identifying individuals, has also increased, leading to more favorable estimations of LGBT individuals (Lance 1987, Herek 1988), as well as increased support for LGBT issues (Flores 2015, Garner 2013, Merino 2013, Tadlock, Flores, Haider-Markel, Lewis, Miller \& Taylor 2017) : $^{3}$

In light of these developments, how precisely has US public opinion towards LGBT individuals and rights changed over time? To explore this question, I now proceed to examine trends in mass opinion towards LGBT individuals themselves, as well as public support for LGBT rights One of the earliest measures of public opinion towards gays and lesbians was the 101-point feeling thermometer in the American National Election Study (ANES). The ANES have asked respondents about their feelings towards gays and lesbians in every wave since 1984, allowing me to track how mass opinion towards sexual minorities has changed over time. These trends can be seen more clearly below in Figure 1. Figure 1 depicts the estimated level of favorability towards gays and lesbians in each wave of the ANES since 1984 4

Beginning in 1984, the estimated level of favorability towards gays and lesbians was just 31 points out of a possible 100 on the thermometer scale, or indicative of very cool or unfavorable estimations. Since 1984, however, these estimations have begun to trend (al-

\footnotetext{
${ }^{3}$ In addition to intergroup contact, increased support for LGBT rights may also be driven by increased exposure to pro-LGBT media frames (Brewer 2003)

${ }^{4}$ Given the tendency of respondents to assign higher ratings to social groups (Wilcox et al. 1989), levels of favorability are estimated while adjusting on a vector of covariates, including party ID, ideology, race, age, gender, education, religion, and region.
} 
Figure 1: Trends in Favorable Estimations Towards Gays and Lesbians, 1894-2016

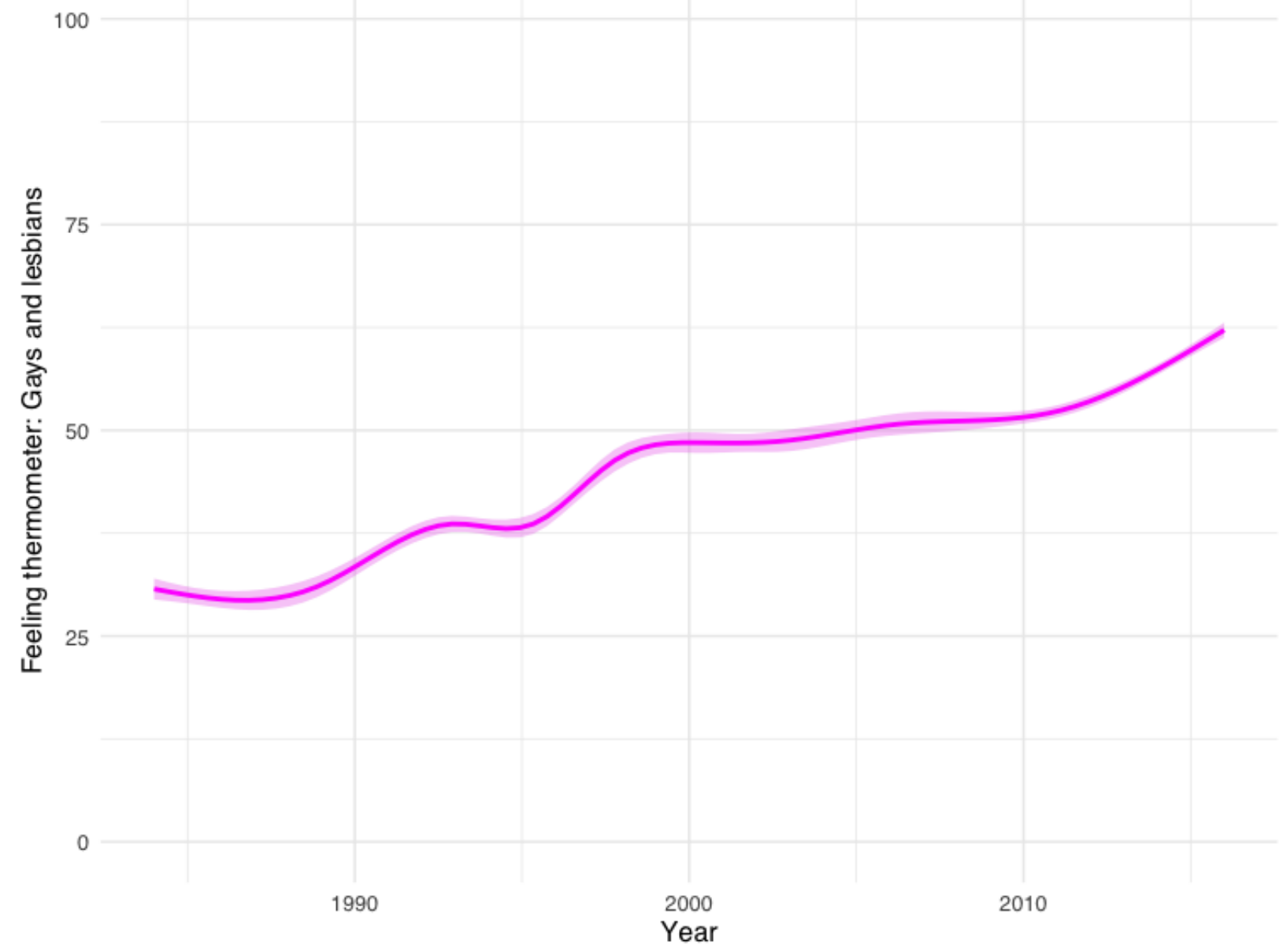

Notes: Points represent the estimated level of favorability towards gays and lesbians in each wave of the ANES. The shaded ares are 95 percent confidence intervals. Model controls for party ID, ideology, race, age, gender, education, religion, and region.

beit quite gradually) in the direction of increasing levels of favorability. 2008 marked the first year that the US public registered a level of favorability towards gays and lesbians that was higher than 50 points (or neutral as opposed to negative feelings) on thermometer. By 2016, the estimated level of favorability towards gays and lesbians was 60 points, a 29-point increase in favorability since 1984.

Given these trends in favorable estimations towards gays and lesbians, might we also expect to see increased support for pro-LGBT policies over time? To gauge trends in public support for pro-LGBT policies, I turn to historic public opinion data from Gallup, 
Figure 2: Trends in Public Support for LGBT Rights, 2001-2021

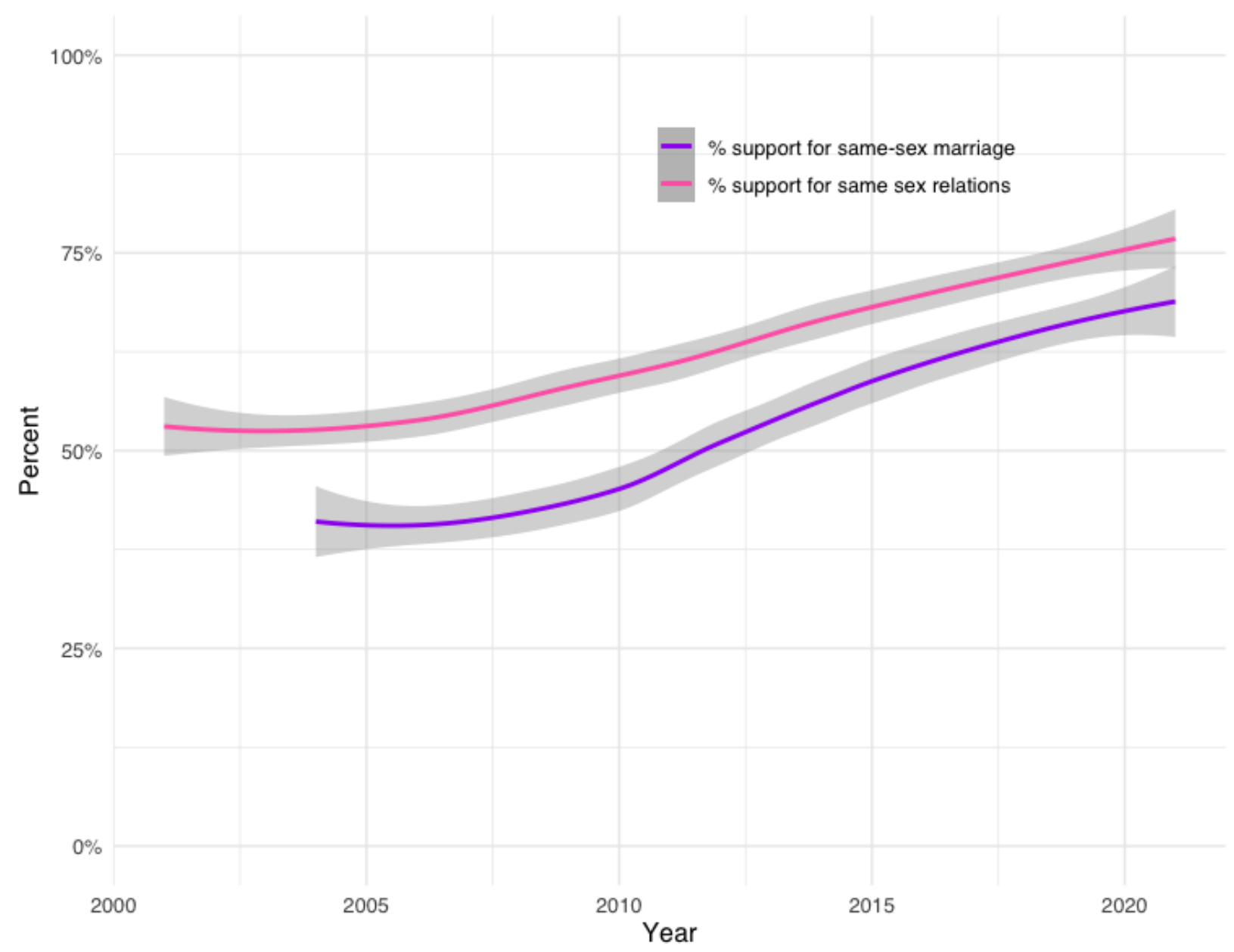

Notes: Lines represent the level of support for same marriage marriage and the legalization of same-sex relations between consenting adults, by year. Data are smoothed using local (loess) regression.

who have collected data on public opinion towards LGBT rights since 1977.55 For brevity, I plot trends in public opinion for two of the most salient issues in the area of LGBT rights in the last two decades - namely, support for the legalization of same-sex marriage, and support for the legalization of same-sex relations between consenting adults. 6

As evidenced by Figure 2, public support for same-sex marriage and the decriminalization of same-sex relations has increased markedly since the early 2000s. In 2003, the

\footnotetext{
${ }^{5}$ https://news.gallup.com/poll/1651/gay-lesbian-rights.aspx

${ }^{6}$ The legalization of same-sex marriage and the decriminalization of same-sex relations are salient topics in the context of the current study because policy change was engendered by the Supreme Court in Lawrence v. Texas and Obergefell v. Hodges, respectively.
} 
year that Lawrence $v$. Texas was decided, public support for decriminalizing same-sex relations stood at $53 \%$. By 2021, this figure in had increased to $79 \%$ an increase in support of $26 \%$. Moving onto same-sex marriage, in 2004, just $42 \%$ of the American public supported legalization. By 2021, however, this figure was 70\%, an increase in public support of 28 points relative to 2004. In both cases, it is important to note that public support for LGBT rights has evolved from bare-majority (in the case of support for decriminalizing same-sex relations) and a minority (in the case of support for same-sex marriage) to strong majority support over the last two decades. The trends observed in the Gallup data thus lend weight to the argument that increases in favorability towards LGBT individuals have coincided with increased support for policies that benefit those who identify as sexual minorities.

\section{Supreme Court Decisions and Their Effects on Mass Opin- ion}

A plethora of evidence suggests that policy implementation can trigger a policy feedback mechanism which, in turn, facilitates a change in mass opinion towards a given issue (Campbell 2012, Eisner, Turner-Zwinkels \& Spini 2021, Jacobs \& Metler 2018, Kreitzer, Hamilton \& Tolbert 2014, Soss \& Schram 2007). Alongside the President and Congress, much attention has been paid to how the Supreme Court shapes public opinion via policy implementation (Franklin \& Kosaki 1989, Hoekstra 2003).7 Models examining the effects of Supreme Court decisions on mass opinion towards LGBT individuals point to a number of possible effects, including backlash, legitimacy, polarization, and consensus (Flores \& Barclay 2016). In this section, I appraise the relevance of each model for understanding

\footnotetext{
${ }^{7}$ This interpretation rests on Dahl (1957) seminal argument that United States Supreme Court Justices are better viewed as "part of the national governing coalition" than as independent legal guardians of the rights on non-majorities. This view of the Court is premised on the assumption that SCOTUS is a policymaking body, and that the President chooses judicial nominees on the basis of whether their judicial philosophy and views conform with those of the President's party.
} 
how Bostock engendered attitude change towards LGBT individuals.

I first turn to discuss the relevance of the legitimacy and consensus models. The legitimacy model posits that policy implementation from government actors imbues a new policy with increased legitimacy through citizens' respect for the rule of law (Scheingold 2004). Evidence suggests that the direction which the Supreme Court rules on a case is likely to give legitimacy to one side of the policy debate. Consistent with this reasoning, multiple studies point to more positive estimations towards LGBT individuals, as well increased support for same-sex marriage, in the wake of cases such as Obergefell v. Hodges (Flores \& Barclay 2016, Kazyak \& Stange 2018, Tankard \& Paluck 2017). Given that mass attitudes towards LGBT individuals trended in the direction of increasing favorability after Obergefell, there is reason to expect that Bostock likewise engendered to more favorable estimations of LGBT individuals among the wider public. Alternatively, if the expectations of the legitimacy model do not hold constant, then we would expect mass opinion towards LGBT individuals to be unmoved by exposure to news about the announcement of Bostock. This outcome would be consistent with the expectations of the consensus model, which posits that institutions such as the Supreme Court are constrained in their ability to lead social change (Casillas et al.2011). In this respect, the consensus model acts as a null model of public opinion change. These developments lead me to state my first hypothesis as:

H1: Favorable estimations of LGBT individuals among the wider public will increase after quasi-random exposure to the announcement of Bostock (legitimacy model).

H0: Favorable estimations of LGBT individuals among the mass public will nether increase nor decreases after quasi-random exposure to the announcement of Boatock (consensus model).

Prior to Obergefell, studies found strong support for the backlash model as frame for 
understanding the impact of Supreme Court decisions on mass opinion towards LGBT rights (Klarman 2012, Stoutenborough, Haider-Markel \& Allen 2006). Policy proponents often fear opinion backlash from the mass public. Opinion backlash is characterized by a large, negative, and enduring shift in mass attitudes that occurs in response to a policy that threatens to upend the status quo (Bishin et al. 2016). Certainly, any policy that is sufficiently salient and challenges existing norms may trigger a backlash. Nevertheless, attempting to engender policy change on a particularly contentious issue is especially likely to trigger a backlash, since it will antagonize those with deeply entrenched views on one side on the debate. The intensity of opinion backlash is likely to be conditional upon which actor or political institution engenders policy change. Since direct democratic institutions (i.e., Congress and the President) are inherently responsible for implementing the majority will, policy implementation via the courts may trigger an especially intense opinion backlash (Price \& Keck|2015).

Despite evidence suggesting that recent Supreme Court decisions on LGBT rights moves mass opinion in the pro-LGBT direction (Flores \& Barclay 2016), the potential for backlash among certain sections of the American public nonetheless remains. While it is evident that mass opinion towards LGBT individuals has become more liberal in recent decades (see Figures 1-2, actions that extend rights to LGBT persons have continued to meet resistance. Much of the contemporary opposition against LGBT rights- whether it be the right for transgender individuals to use the bathroom that corresponds to their gender identity, access to health benefits, or the right to adoption - is concentrated among the religious. Indeed, religious variables including affiliation and frequency of religious service attendance are among the strongest concomitants of opposition to LGBT rights (Olson et al. 2006). Among religious adherants, Evangelical Protestants are repeatedly found to be some of the staunchest opponents of LGBT rights (Cox, Navarro-Rivera \& Jones 2014, Ayoub \& Page 2020, Bishin, Hayes, Incantalupo \& Smith 2016). These developments lead me to state my second hypothesis as: 
H2: Favorable estimations of LGBT individuals among Evangelical Protestants will decrease after quasi-random exposure to the announcement of Bostock (backlash model).

Lastly, contemporary debates in the political science scholarship point to an ongoing partisan and ideological sort among the American public (Levendusky 2009, Mason 2015). Consequently, socio-political attitudes such as partisan identity and ideology are likely to shape how individuals react to contentious policy decisions. LGBT rights are a salient example of an issue where individuals are highly polarized by factors such as partisanship, with Republicans generally exhibiting less favorable estimations of LGBT individuals and being more likely to organize in opposition to LGBT rights, and Democrats exhibiting more favorable estimations and being more likely to organize in support of LGBT rights (Castle|2019, Castle \& Stepp 2021, Lewis, Flores, Haider-Markel, Milller, Tadlock \& Taylor 2017). Given the nature of socio-political sorting and its impact on public attitudes towards a variety of issues, there is reason to expect asymmetric reactions to the announcement of Bostock when individuals are contrasted on their partian identities. These developments lead me to state my final hypothesis as:

H3: Favorable estimations of LGBT individuals will increase among Democrats and derease among Republicans after quasi-random exposure to the announcement of Bostock (polarization model).

\section{Data and Methods}

\subsection{Data}

To assess whether Bostock led to attitude change towards LGBT individuals, I utilize data from the 2019-2020 Democracy Fund/UCLA Nationscape survey. Nationscape is a na- 
tionally representative, online-based 16-month election survey conducted by researchers at UCLA. The initial fieldwork for the Democracy Fund/Nationscape Survey was conducted in 2 phases. Phase 1 of the survey was conducted between July 2019 and December 2019, while Phase 2 was conducted between January 2020 and July 2020. During these first two phases, Nationscape interviewed a total of $\mathrm{N}=318,000$ US adults.

\subsection{Research Design}

My strategy for identifying local causal effects is derived from the event study framework Muñoz et al. (2020). Bostock was announced on June 15, 2020, thus taking place during fieldwork for Phase 2 of the Nationscape survey. The quasi-random nature of event exposure provides a setting in which I can identity the impact of the decision on public favorability towards gays and lesbians after it occurred (Muñoz et al.|2020).

To estimate local causal effects, I constrain the temporal horizon to a bandwidth of \pm 16 days relative to treatment. $8^{8}$ Doing so aids in my ability to isolate the local causal effect of quasi-random exposure to the announcement of Bostock on my key outcome of interest. In additional analyses, I demonstrate that alternative bandwidths to not substantively affect the direction and significance of the results presented here. Results of my models using alternative bandwidth are presented in section A1 of the Supplementary Appendix.

An important impediment to local causal identification outlined by Muñoz et al. (2020) is violation of the ignorability assumption. To address concerns related ignorability, I utilize an entropy balancing estimator to maximize covariate balance across treatment and control groups.99 Entropy balancing is a multivariate reweighting method that reweights

\footnotetext{
${ }^{8}$ This decision is informed by several considerations. The first relates directly to statistical power: 16 days should provide sufficiently balanced and large enough samples for detecting small differences. A bandwidth of 16 days should also be wide enough to generate enough observations for detecting small attitudinal changes while being narrow enough to mitigate threats to excludability. Finally, a 16-day bandwidth corresponds to the period between the announcement of the Bostock decision (June 15, 2020) the final survey day (July 1, 2020).

${ }^{9}$ Balance analysis reveals minor but no statistically significant differences between covariates. Full balance analysis statistics are presented in section A2 of the SI file.
} 
the Nationscape dataset such that covariate distributions in the reweighted data satisfy a set of specified moment conditions. The estimator is thus useful in creating balanced samples in studies such as mine with a dichotomous treatment, where the control group data are ideally balanced to match the covariate moments in the treatment group. I implement my balance analysis using the ebalance function in Stata (Hainmueller \& Xu 2013 ). 10

Assessing violation of the ignorability assumption also requires that I test whether my estimates are biased by asymmetric attrition (Muñoz et al. 2020). A particular concern is that quasi-random exposure to the announcement of Bostock itself may increase the willingness of certain individuals to respond. For instance, any backlash against the ruling may engender a sense of anger or moral outrage among strong Republican partisan identifiers and Evangelical Christians, thus making them more likely to respond. In my tests for asymmetric attrition, I demonstrate that treatment assignment does not condition a Nationscape respondents' willingness to provide a response to the dependent measure (see section A4 of the SI file).

Lastly, another important assumption that underpins the "unexpected event" framework is that the event itself is salient and one that survey respondents quasi-randomly assigned to the treatment group were likely to have been aware of Muñoz et al. (2020). To gauge the level of popular interest in the Bostock decision and LGBT rights, I turn to Google Trends data for the US. Figure 2 graphs the relative level of interest in the terms "Supreme Court," "Bostock v. Clayton County," and "LGBT." As indicated by Figure 2, all of these terms saw a significant spike in interest after Bostock was announced. These trends thus point to the Bostock decision being an event of interest within the US and signals the relative salience of LGBT issues around the time of its announcement (Mellon 2014).

\footnotetext{
${ }^{10}$ The entropy estimator performs extremely well in balancing the set of covariates. Full covariate adjustment statistics are reported in section A3 of the SI file.
} 
Figure 3: Popular Interest in "Supreme Court," "Bostock v. Clayton County," and "LGBT"

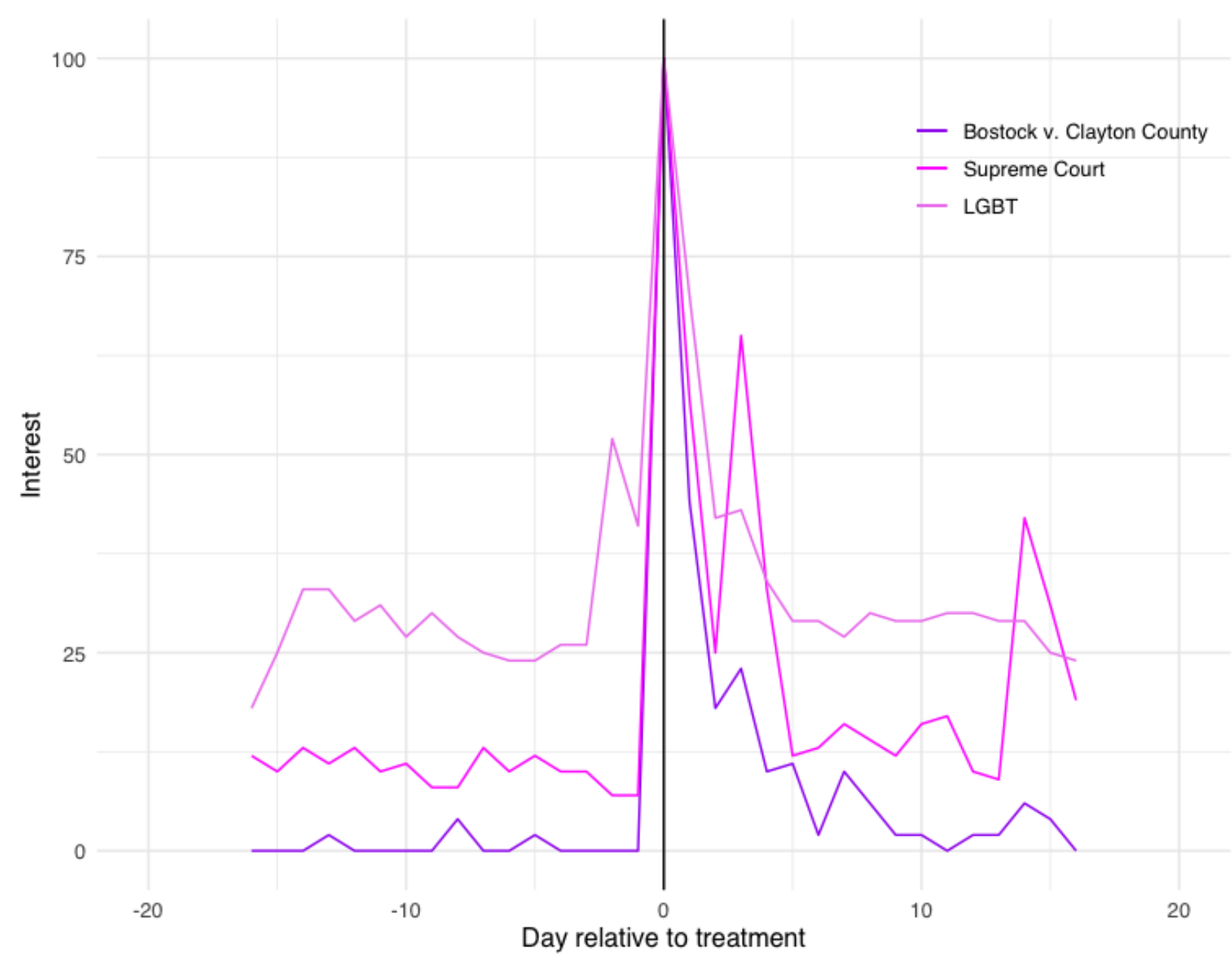

Notes: Lines represent the level of interest in "Supreme Court," "Bostock v. Clayton County," and "LGBT," as search terms on Google between May 30 and July 1, 2020. Day of the announcement of Bostock, (June 15) indicated by the vertical black line. Limited to searches made in the US.

\subsection{Dependent Measure}

The dependent measure is a five-point ordinal item that asks respondents how favorable they feel towards gays and lesbians, with possible responses ranging between 1 = "very favorable," to $5=$ "very unfavorable." For ease of interpretation, I dichotomize respondents to those who are favorable towards gays and lesbians (1) and those who unfavorable/ have not heard enough (0). 


\subsection{Quasi-Experimental Treatment}

Treatment assignment is operationalized with a dichotomous measure that codes respondents surveyed between May 30-June 14 as 0 (the control group) and those surveyed between June 15-July 1 as 1 (the treatment group).

\subsection{Controls}

The effect of the treatment on favorability towards gays and lesbians is adjusted by controlling for partisanship (seven-point ordinal item ranging between 1 = "strong Democrat," to $7=$ "strong Republican") , ideology (5-point ordinal item ranging between $1=$ "very liberal," to 5 = "very conservative"), age (in years), gender (dichotomous measure where $1=$ "male," $0=$ "female"), education (eleven-point ordinal item ranging between $1=$ "3rd grade or less," to $11=$ "doctoral degree", religion (dichotomous measures for Evangelical Protestant, Catholic, other Christian, non-Christian, and the religiously unaffiliated, with mainline Protestants serving as the base category), and region (dichotomous measure where 1 = "South," 0 = "non-South") 11

\subsection{Model}

My key term of interest is the intent to treat (ITT) effect of the quasi-random assignment to the treatment condition. The model specification is summarized in the basic model in which $\beta_{1}$ is the covariate adjusted intent to treat effect, $\left.y_{(} X^{i}\right)$ is a vector of individual covariates (party ID, ideology, age, gender, education, religion, and region), and $\epsilon_{i}$ is the error term:

\footnotetext{
${ }^{11}$ Nationscape does not contain measurement for frequency of contact with LGBT individuals. This is somewhat problematic given that contact may lead to more positive estimations of LGBT individuals (Lance 1987. Herek 1988). To address the issue of omitted variable bias and possible unobserved confounding that may arise from the absence of measures for group contact, I performed a sensitivity analysis on all models using the konfound package in Stata (Xu et a, 2019). Sensitivity analysis for unobserved confounders in the non-parametric models was assessed via the percentage of bias necessary to invalidate the inferences from each model. The results of the respective models are presented in section A5 of the SI file.
} 


$$
\left.Y_{i}=a+\beta_{1}+y_{(} X^{i}\right)+\epsilon_{i}
$$

Given that my outcome measure of interest is dichotomous, models are estimated using probit ${ }_{12}^{12}$ In my test of $\mathbf{H 1}$, models are estimated using the full sample of Nationscape respondents who took the survey within the \pm 16 -day bandwidth relative to treatment $(\mathrm{N}$ $=31,007)$. In order to test $\mathbf{H} \mathbf{2}$ and $\mathbf{H} \mathbf{3}$, I rely on a series of partisan and religiously stratified subsamples.

\section{Results}

I first present the results of my models examining the effect of quasi-random exposure to the announcement of Bostock on favorable estimations of gays and lesbians among the wider public. Should the theoretical expectations of the legitimacy model hold constant, we should expect the treatment to exert a positive and significant effect on the dependent measure in the direction of greater favorability towards gays and lesbians (H1). Figure 4 presents the estimated effects of the treatment on the dependent measure. In line with $\mathbf{H 1}$ and the previous scholarship on the effects of Supreme Court decisions on mass opinion post-Obergefell, the treatment exhibits a significant effect on the dependent measure ( $p$ $<.01)$. We can therefore successfully reject the null hypotheses $(\mathrm{H} 0)$ that exposure to the announcement of Bostock will neither increase nor decrease favorable estimations of LGBT individuals. 13

To get a more substantive approximation of the effects of the treatment on the dependent measure, I plot the pre-and post-treatment probabilities that a Nationscape respondent will exhibit favorable estimations of gays and lesbians (see Figure 5). The difference

\footnotetext{
${ }^{12}$ Replications using an ordered probit estimator do not substantively alter the significance and direction of the results presented in the main paper (see section A6 of the SI file).

${ }^{13}$ Though it is not my main focus here, Figure 4 also indicates a number of significant effects through the set of covariates. Republican partisanship and political conservatism are both associated with a lower probability of a nationscape respondent exhibiting favorable estimations of gays and lesbians, as is age, being an Evangelical Protestant, being a non-Protestant or non-Catholic Christian, and being a non-Christian religious adherent (all $p<.001$ ). Lastly, Being White is associated with an increased probability of exhibtiing favorable estimations towards gays and lesbians, as is being highly educated (both $p<.001$ )
} 
Figure 4: Modelling Favorability Towards Gays and Lesbians

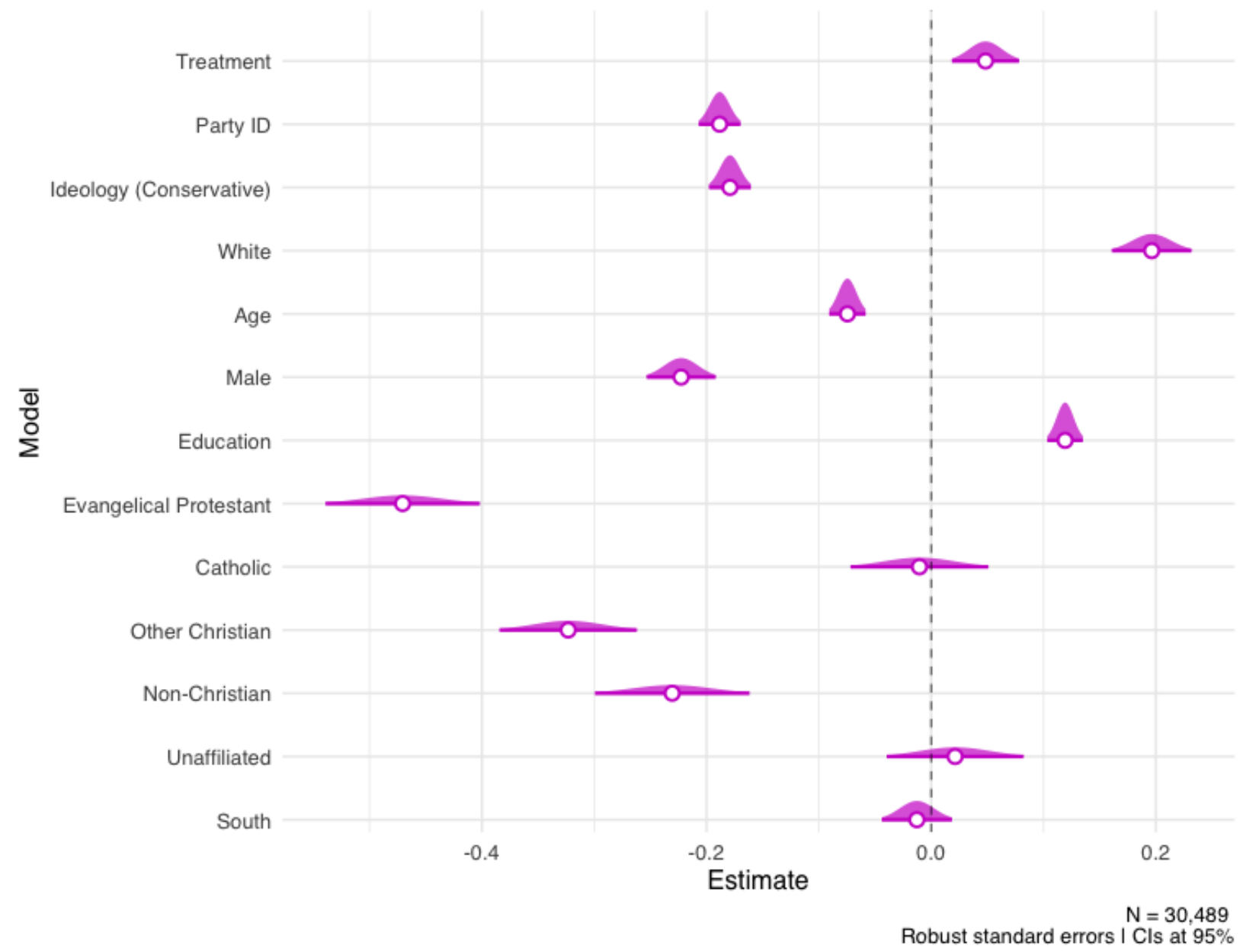

Notes: Points represent the marginal effect of each variable on favorability towards gays and lesbians. Data are entropy weighted. Full model output presented in section B1 of the SI file.

in pre-and post-treatment probabilities is expressed as the average local treatment effect (LATE) of the effect of quasi random exposure to the announcement of Bostock. Adjusting on my set of covariates, I find that $63.7 \%$ of Nationscape respondents exhibited favorable estimations of gays and lesbians before the announcement of Bostock, and 65.7\% exhibited favorable estimations afterward - a statistically significant increase of two percent (LATE $=.02, p<.001)$. 
Figure 5: Local Average Treatment Effect on Favorability Towards Gays and Lesbians

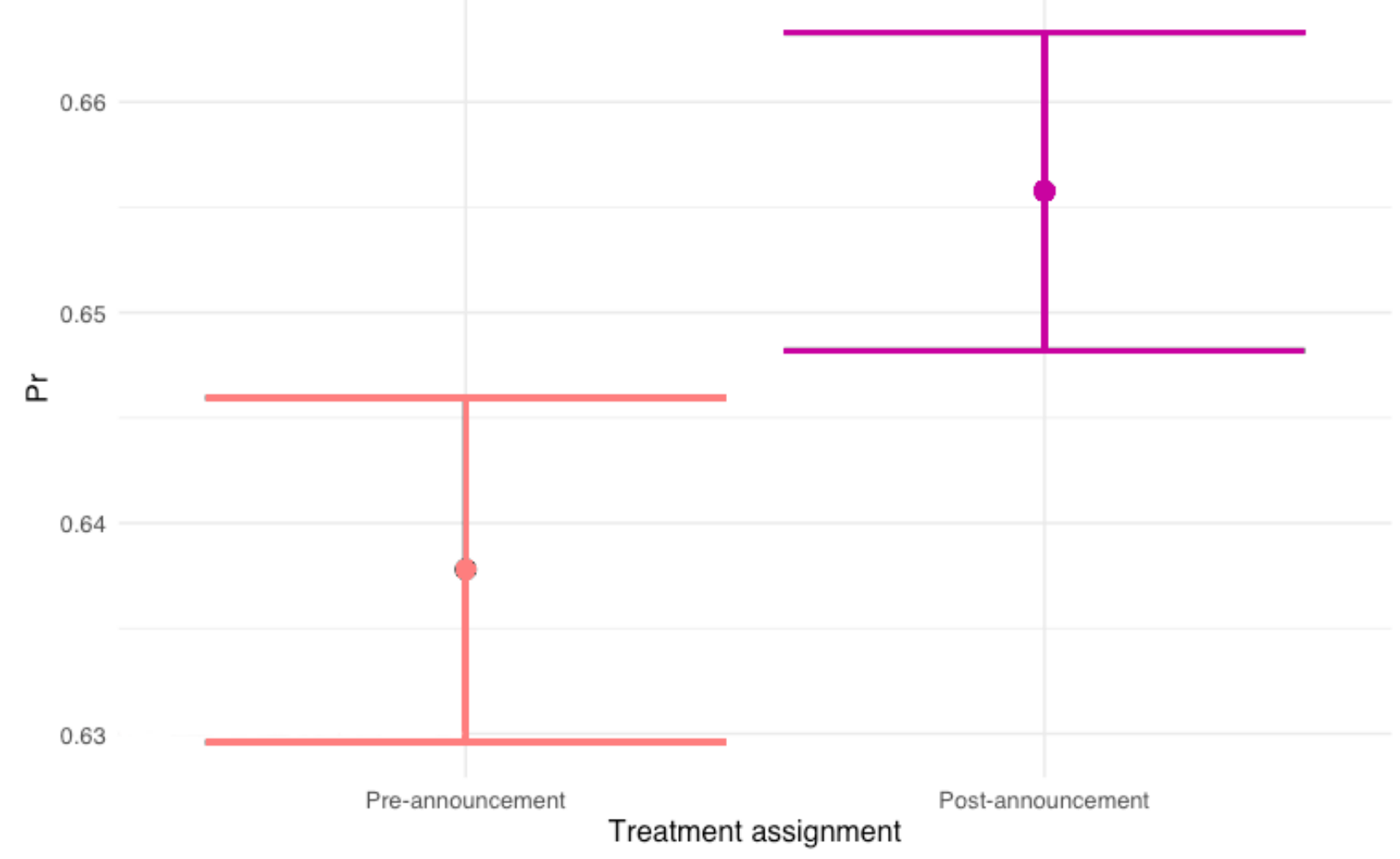

Notes: Points represent the pre-and post-treatment predicted probabilities. The capped lines are 95 percent confidence intervals.

\subsection{Subgroup Analyses: Party ID and Religion}

H2 posited that there would be also asymmetric responses to the announcement of Bostock among religious and nonreligious respondents. To test this possibility, I speccify a series of models where the effects of the treatment are estimated separately for mainline Protests, Evangelical Protestants, Catholics, other Christians, non-Christians, and the religiously unaffiliated. Figure 6 displays the pre-and post-treatment probabilities of a given Nationscape respondent exhibiting favorable estimations of gays and lesbians when categorized by their religious identity.

For the Evangelical Protestant subsample, the effect of the treatment is in the expected direction (i.e, quasi-random exposure to Bostock leads to less favorable estimations of LGBT individuals), but these changes are not sufficently large to be statistically distin- 
Figure 6: Asymmetric Local Average Treatment Effects, by Religion

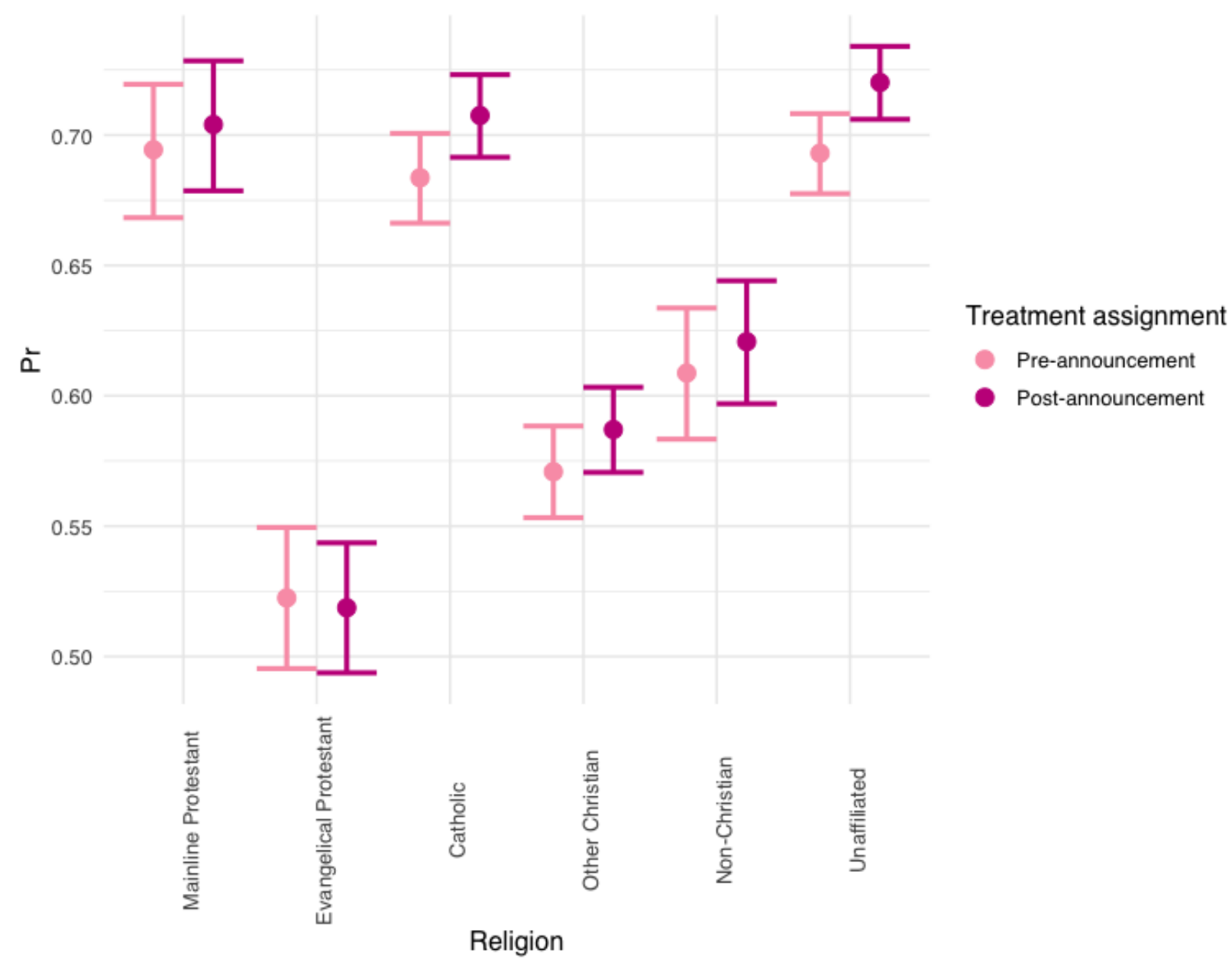

Notes: Points represent the pre-and post-treatment predicted probabilities for each religious subsample. The capped lines are 95 percent confidence intervals. Full model output presented in section B2 of the SI file.

guishable from zero. Therefore, we fail to find evidence in favor of the backlash thesis among Evangelical Protests (H2). Indeed, comparing levels of favorability towards LGBT individuals, it is interesting to note that there are no significant changes among the religious subsamples. In the case of the religiously unaffiliated, however, there is a small-but identifiable effect. Pre-announcement, $69.3 \%$ of the religiously unaffiliated exhibited favorable estimations towards LGBT individuals, while post announcement, $72 \%$ exhibited favorable estimations, a statistically significant increase of $2.7 \%$ (LATE $=.027, p<.001$ ).

Lastly, $\mathbf{H} 3$ posited that there would be asymmetric responses to the announcement 
of Bostock among individuals with different partisan identities. To test this expectation, I specify a series of four models where the effects of quasi-random exposure to the announcement of Bostock are estimated separately for Democrats, Republicans, Independents, and partisans who identify as "something else." ${ }^{14}$ Figure 7 depicts the pre-and post-treatment probabilities of a Nationscape respondent exhibiting favorable estimations of LGBT individuals while adjusting on my set of covariates. Once again, the difference in pre-and post-treatment probabilities is expressed as the estimated local average treatment effect (LATE).

As evidenced by Figure 7, 70.8\% of Democratic partisans exhibited favorable estimations of LGBT individuals before the announcement of Bostock compared to $73.5 \%$ postannouncement, a statistically significant increase in favorability of 2.7\% (LATE $=.027, p$ $<.001$ ). Pre-announcement, $64.1 \%$ of Independents and $57.4 \%$ of Republicans exhibited favorable estimations of LGBT individuals, respectively. Post-announcement, however, $58.4 \%$ of Republicans and $64.8 \%$ of respondents exhibited favorable estimations. Though the announcement of the decision saw increases in favorability towards LGBT individuals among Independents $(.7 \%)$ and Republicans (1\%), it is important to qualify that the magnitude of these changes are not statistically distinguishable from zero. Finally, 51.6\% partisans who do not identify as Democrats, Independents, or Republicans exhibited favorable estimations of LGBT individuals before the announcement of Bostock compared to $56.7 \%$ who did afterwards - a statistically significant increase in favorability of $5.1 \%$ relative to pre-treatment $(\mathrm{LATE}=.051, p<.001)$. Given that increases in favorability towards gays and lesbians among Democratic partisans did not coincide with decreases in favorability among Republican partisans, we find mixed results in support of $\mathbf{H 3}$

\footnotetext{
${ }^{14}$ To avoid concerns related to multicollinearity, the seven-point scale party ID is dropped from these models. Interacting the treatment with the categorical variable for party ID does not alter the direction and significance of the results presented here. Estimates available on request.
} 
Figure 7: Asymmetric Local Average Treatment Effects, by Party ID

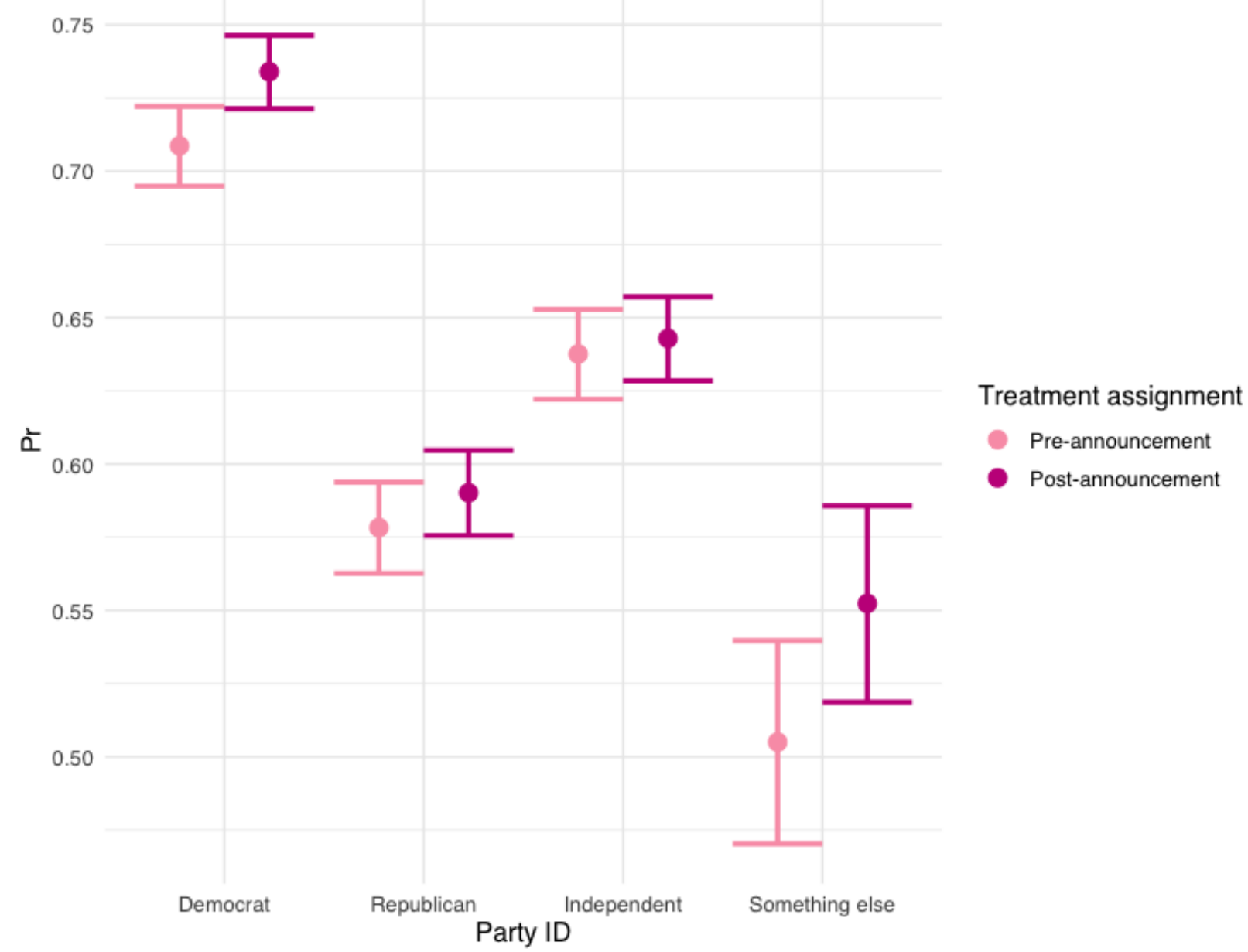

Notes: Points represent the pre-and post-treatment predicted probabilities for each partisan subsample. The capped lines are 95 percent confidence intervals. Full model output presented in section B3 of the SI file.

\subsection{Robustness Tests}

To provide further evidence of a local causal effect on favorability towards gays and lesbians through the treatment, I now present a series of robustness tests. First, the exclusion restriction requires that the timing of survey fieldwork for Nationscape only affects my outcome of interest through exposure to the announcement of Bostock (Muñoz et al. 2020). The most relevant threats underpinning this assumption being that the results are simply the result of chance or are a function of pre-existing time trends. To satisfy the exclusion restriction, I conduct a falsification test that tests for the presence of a significant effect 
where one ought not to exist. As recommended byMuñoz et al. (2020), I use the median interview date of the control group sample as the placebo cut-off date (December $22,2019)$. Section $\mathrm{C} 1$ of the SI file contains an addition model where favorability towards gays and lesbians is modelled as a function of the placebo cut-off. As indicated here, using the empirical median of the control group subsample as the cut-off date does not produce significant results.

In my next robustness test, I demonstrate that the effect of quasi-random exposure to the announcement of Bostock on mass opinion towards gays and lesbians has an insignificant effect on a variety of measures that ought to have a tenuous connection to the case. Section C2 of the SI file presents the results of a series of placebo models estimating the effect of the treatment on public favorability towards Whites, White men, Blacks, Latinos, Asians, Jews, Evangelical Christians, socialists, labor unions, Democrats, and Republicans. Should quasi-random exposure to the announcement of Bostock affect attitudes towards LGBT individuals, de minimis, then we should expect to observe an insignificant pattern of results across the placebo models. The results of these models indeed indicate that the treatment imparts no significant effect on any of the placebo dependent measures. Therefore, we can be reasonably confident that the treatment is shaping public attitudes towards gays and lesbians in particular and no other groups in US society.

In my final test, I demonstrate that the significant effects on the dependent measure through quasi-random exposure to the announcement of Bostock is not primarily driven by increases in in-goup favoritism among Nationscape respondents who identify as sexual minorities. Section C3 of the SI file presents the results of an additional model where I limit my sample to respondents who identify as heterosexual/straight. As indicated here, the treatment remains a statistically significant predictor of favorability towards LGBT individuals $(\beta=.018, p<.05)$. 


\section{Discussion}

Models gauging the effects of Supreme Court decisions on mass opinion towards LGBT individuals point to a number of possible effects, including legitimacy (increased favorability towards LGBT individuals), consensus (no discernable increase or decrease in favorable estimations), backlash (decreased favorability), and polarization (asymmetric effects) (Flores and Barclay 2016). Previous studies examining the impact of cases such as Obergefell $v$. Hodges on mass opinion towards LGBT individuals found strong support for the legitimacy model (Flores \& Barclay 2016, Kazyak \& Stange 2018, Tankard \& Paluck 2017). Despite the clear contribution of these papers in furthering our scholarly understanding of how Supreme Court decisions increase public support for LGBT individuals and rights in the case of same sex marriage, however, it was not altogether clear whether we might have observed similar effects when it came to a case on LGBT employment rights. As I have argued throughout this paper, testing for this possibility is critically important, as it would lend further weight to the theoretical expectations of the legitimacy model, and would also increase its generalizability by demonstrating that favorable estimations of LGBT individuals increase in the wake of Supreme Court opinions on LGBT rights beyond those concerning the legalization of same-sex marriage.

The present study represents an important step in addressing this critical lacuna. In

this paper, I have explored whether favorable estimations of LGBT individuals among the wider public increased as a result of quasi-random exposure to the announcement of Bostock (legitimacy model). To lend further weight to the expectations of the legitimacy model, I have also tested the robustness of the backlash and polarization models in subgroup analyses. Given the increased mobilization and organization of the religious right in opposition to LGBT rights in the post-Obergefell era (Ayoub \& Page|2020), I have tested for the possibility that favorable estimations of LGBT individuals among religious adherents - and in particular Evangelical Protestants - decreased after quasi random exposure to the announcement of Bostock (backlash model). Finally, given the extent of sociopoliti- 
cal polarization and sorting among the American public (Levendusky|2009), I also tested for the possibility that there were asymmetric reactions through to quasi-random exposure to the announcement of Bostock when individuals are contrasted on their partisan identities (polarization model).

This paper provides three important contributions to the extant scholarship on the effects of Supreme Court decisions on mass opinion towards LGBT individuals. First, it provides additional (quasi) experimental evidence that Supreme Court decisions on LGBT rights are able to move mass opinion towards LGBT individuals in an increasingly liberal direction after exposure to news about the case. The case for legitimacy was observed in my model estimating the effects of quasi-random exposure to news about the announcement of Bostock among the wider public (see Figure 4). In substantive terms, I found that quasi-random exposure to Bostock was associated with an estimated two-point increase in favorability towards gays and lesbians $(p<.001)$. While the magnitude of this increase is rather small, it is important to contextualize this finding within the broader scholarship. When we do so, we find that this increase is consistent with that of similar studies (Bishin, Hayes, Incantalupo \& Smith 2016, Flores \& Barclay|2016). It is also important to note that a two-point increase in favorability among the wider public is broadly consistent with longer term-trends in favorability towards gays and lesbians observed in the ANES data (see Figure 1). As observed here, favorability towards gays and lesbians has risen incrementally over time, rather than being driven by particularly large increases between survey waves. As such, we can be relatively certain that the results concerning the impact of Supreme Court decisions such as Bostock on mass attitudes towards LGBT individuals comport to a broader pattern of steadily increasing favorability over time.

Second, while the extant scholarship has focused on the impact of Supreme Court decisions concerning same sex marriage (Flores \& Barclay 2016, Kazyak \& Stange 2018, Tankard \& Paluck 2017), this paper quantifies that SCOTUS opinions beyond same-sex marriage legalization are able to impart significant changes in mass opinion towards 
LGBT individuals in the direction of increasing favorability. This finding is significant because it extends the generalizability of the legitimacy model to include cases on antiLGBT discrimination in areas such as employment. It is also significant because it confirms that Obergefell did not produce a ceiling effect on mass opinion towards LGBT individuals. There was some reason to expect that this might have been the case, given Stoddard (1997) hypothesis that same-sex marriage legalization would "lead to a world free from discrimination against lesbians and gay men." Though Obergefell was a significant step forward in the fight for extending rights for LGBT individuals, ongoing cases concerning the ability of employers to discriminate against their employees on the basis of sexual and gender identity provided robust evidence that there was still room for mass opinion towards LGBT individuals increase if a similar outcome was reached in Bostock. In this respect, the findings suggest that, provided that inequality towards LGBT individuals still exists, and a large enough percentage of the American public remain ambivalent, support for LGBT individuals may keep increasing if they see institutions such as the Supreme Court continue to perform their role of norm-legitimizing via ruling in the liberal direction on LGBT rights.

Finally, the results cast further doubt on the robustness of the backlash model as a means of understanding mass opinion towards LGBT individuals post-Obergefell. The insignificant pattern of results for the effects of quasi-random exposure to the announcement of Bostock on favorability towards LGBT individuals among the Evangelical Protestant subsample are consistent with the findings of Bishin et al. (2016), who similarly detect changes in attitudes towards the group that are statistically indistinguishable from zero. The fact that we observed significant effects through the treatment for the religiously unaffiliated suggests that my inability to detect opinion changes among the Evangelical Protestant subsample is not simply a function of a failure to treat that group. While there was clear evidence of a backlash in the aftermath of Botock among publicly visible religious leaders (Bailey 2020), the null results in my subgroup analysis point to an 
interesting disconnect between their public moral outrage and the apparent indifference towards the announcement of Bostock among of many Americans who remain religiously affiliated These findings are important because they provide further evidence in favor of the argument that elected representatives and jurists alike should not fear opinion backlash among the religiously affiliated in response to policy implementation on particularly contentious social issues.

Notwithstanding this possibility, it is important to note that favorable estimations towards LGBT individuals have been increasing among all sections of the wider public, including the religiously affiliated. Though it is reasonable to expect that factors such as moral traditionalism mean that favorability towards LGBT individuals among religious affiliates has not increased as sharply as it has among the religiously unaffiliated over time (Brewer 2003, Cao \& Gurcay 2021), it is important to note that Evangelical Protestants still exhibited net-favorable estimations of LGBT individuals post-Bostock (see Figure 6. As such, even if quasi-random exposure to the announcement of Bostock engendered a statistically significant decline in favorability, it is important to qualify that this decline might not have been sufficiently large to reduce net-estimations to a state of unfavorability.

\subsection{Limitations and Future Directions}

It is also important to highlight the limitations of the current study, as well as to point to potential avenues for future research. One limitation of the current study is the absence of survey items gauging public support for pro-LGBT policies in the Nationscape dataset. A particular strength of prior studies is that they have contained a battery of items gauging attitudes towards LGBT individuals in addition to support for policies such as same sex marriage (Bishin et al. 2016, Flores \& Barclay 2016). In doing so, they have been able to quantify the effects of exposure to Supreme Court decisions such as Obergefell on multiple outcomes (e.g., group affect and support for specific policies), thus increasing the applicability of their findings. Another limitation of the current study is that the announcement 
of Bostock occurred close to the end of the survey fieldwork for Phase 2 of Nationscape, thus limiting my temporal bandwidth to \pm 16 days relative to treatment. While a 16-day measurement of exposure is able to capture any effects on public favorability towards LGBT individuals far longer than exposure to a given experimental condition in a survey experiment, it is important to quantify that similar studies have measured attitudes towards LGBT individuals over a period of one year or greater (Flores \& Barclay|2016). Consequently, there are able to better gauge the long-lasting effects of exposure to Supreme Court decisions on LGBT rights on mass attitudes towards LGBT individuals.

Future studies may seek to quantify the impact of exposure to Supreme Court decisions on LGBT protections in employment from discrimination by including a wider range of outcome measures, including those that are theoretically relevant to treatment for instance, support for laws that would prevent employers from discriminating against individuals based on their sexual or gender identity. 


\section{Bibliography}

Aksoy, C. G., Carpenter, C. S., Haas, R. D. \& Tran, K. D. (2020), ‘Do laws shape attitudes? evidence from same-sex relationship recognition policies in europe', European Economic Review 124, 1-18.

Ayoub, P. M. \& Page, D. (2020), 'When do opponents of gay rights mobilize? explaining political participation in times of backlash against liberalism', Political Research Quarterly 73(3), 696-713.

Bailey, S. P. (2020), ‘Christian conservatives rattled after supreme court rules against lgbt discrimination', The Washington Post .

URL: $\quad$ https://www.washingtonpost.com/religion/2020/06/15/bostock-court-faithconservatives-lgbt/

Bishin, B. B., Hayes, T. J., Incantalupo, M. B. \& Smith, C. A. (2016), ‘Opinion backlash and public attitudes: Are political advances in gay rights counterproductive?', American Journal of Political Science 60(3), 625-648.

Brewer, P. R. (2003), 'Values, political knowledge, and public opinion about gay rights: A framing-based account', Public Opinion Quarterly 67(2), 173-201.

Campbell, A. L. (2012), 'Policy makes mass politics', Annual Review of Political Science $15,333-351$.

Cao, X. \& Gurcay, A. (2021), 'The anxiety factor: Moral traditionalism, interpersonal contact diversity and support for transgender candidates and rights', Journal of Homosexuality pp. 1-24.

Casillas, C. J., Enns, P. K. \& Wohlfarth, P. J. (2011), 'How public opinion constrains the u.s. supreme court', American Journal of Political Science 55(1), 74-88. 
Castle, J. (2019), ‘New fronts in the culture wars? religion, partisanship, and polarization on religious liberty and transgender rights in the united states', American Politics Research 47(3), 650-679.

Castle, J. \& Stepp, K. K. (2021), ‘Partisanship, religion, and issue polarization in the united states: A reassessment', Political Behavior 43, 1311-1335.

Cox, D., Navarro-Rivera, J. \& Jones, R. P. (2014), 'A shifting landscape: A decade of change in american attitudes about same-sex marriage and lgbt issues', PRRI .

Dahl, R. A. (1957), 'Decision-making in a democracy: The supreme court as a national policy-maker', Journal of Public Law 6, 279-295.

Eisner, L., Turner-Zwinkels, F. \& Spini, D. (2021), 'The impact of laws on norms perceptions', Personality and Social Psychology Bulletin 47(7), 1071-83.

Flores, A. R. (2015), 'Attitudes toward transgender rights: perceived knowledge and secondary interpersonal contact', Politics, Groups, and Identities 3(3), 398-416.

Flores, A. R. \& Barclay, S. (2016), 'Backlash, consensus, legitimacy, or polarization: The effect of same-sex marriage policy on mass attitudes', Political Research Quarterly 69(1), 43-56.

Flores, A. R., Mallory, C. \& Conron, K. J. (2020), The impact of Obergefell v Hodges on the well-being of LGBT adults, The Williams Institute, Los Angeles, CA.

Franklin, C. H. \& Kosaki, L. C. (1989), 'Republican schoolmaster: The u.s. supreme court, public opinion, and abortion', American Political Science Review 83(3), 751-771.

Garner, A. (2013), 'Ambivalence, the intergroup contact hypothesis, and attitudes about gay rights', Politics and Policy 41(2), 241-266.

Hainmueller, J. \& Xu, Y. (2013), 'Ebalance: A stata package for entropy balancing', Journal of Statistical Software 54(7), 1-18. 
Herek, G. M. (1988), 'Heterosexuals' attitudes toward lesbians and gay men: Correlates and gender differences', The Journal of Sex Research 25(4), 451-477.

Hoekstra, V. J. (2003), Public reaction to Supreme Court decisions, Cambridge University Press, Cambridge, UK.

Jacobs, L. R. \& Metler, S. (2018), 'When and how new policy creates new politics: Examining the feedback effects of the affordable care act on public opinion', Perspectives on Politics 16(2), 345-363.

Jay, K. \& Young, A. (1992), Out of the Closets: Voices of Gay Liberation, NYU Press, New York City, NY.

Johnson, D. K. (2009), The lavender scare: The Cold War persecution of gays and lesbians in the federal government, University of Chicago Press, Chicago, IL.

Kazyak, E. \& Stange, M. (2018), ‘Backlash or a positive response?: Public opinion of lgb issues after obergefell v. hodges', Journal of Homosexuality 65(14), 2028-2052.

Keck, T. M. (2009), 'Beyond backlash: Assessing the impact of judicial decisions on lgbt rights', Law Society Review 43(1), 151-186.

Kissack, T. (1995), ‘Freaking fag revolutionaries: New york's gay liberation front, 19691971', Radical History Review 62, 104-134.

Klarman, M. (2012), From the closet to the altar: Courts, backlash, and the struggle for same-sex marriage, Oxford University Press, New York City, NY.

Kreitzer, R. J., Hamilton, A. J. \& Tolbert, C. J. (2014), ‘Does policy adoption change opinions on minority rights? the effects of legalizing same-sex marriage', Political Research Quarterly 67(4), 795-808.

Lance, L. M. (1987), 'The effects of interaction with gay persons on attitudes toward homosexuality', Human Relations 40(6), 329-336. 
Levendusky, M. (2009), The partisan sort: how liberals became Democrats and conservatives became Republicans, University of Chicago Press, Chicago, IL.

Lewis, D. C., Flores, A. R., Haider-Markel, D. P., Milller, P. R., Tadlock, B. L. \& Taylor, J. K. (2017), 'Degrees of acceptance: Variation in public attitudes toward segments of the lgbt community', Political Research Quarterly 70(4), 861-875.

Liptak, A. (2020), 'Civil rights law protects gay and transgender workers, supreme court rules', The New York Times .

URL: https://www.nytimes.com/2020/06/15/us/gay-transgender-workers-supreme-court.html

Mason, L. (2015), “i disrespectfully agree”: The differential effects of partisan sorting on social and issue polarization', American Journal of Political Science 59(1), 128-145.

Mellon, J. (2014), 'Internet search data and issue salience: The properties of google trends as a measure of issue salience', Journal of Elections, Public Opinion, and Parties 24(1), 4572.

Merino, S. M. (2013), ‘Contact with gays and lesbians and same-sex marriage support: The moderating role of social context', Social Science Research 42(4), 1156-1166.

Millhiser, I. (2020), 'The supreme court's landmark lgbtq rights decision, explained in 5 simple sentences', Vox .

URL: $\quad$ https://www.vox.com/2020/6/15/21291515/supreme-court-bostock-clayton-countylgbtq-neil-gorsuch

Muñoz, J., Falcó-Gimeno, A. \& Hernández, E. (2020), 'Unexpected event during survey design: Promise and pitfalls for causal inference', Political Analysis 28(2), 186-206.

Olson, L. R., Cadge, W. \& Harrison, J. T. (2006), 'Religion and public opinion about same sex marriage', Social Science Quarterly 87(2), 340-360. 
Price, R. S. \& Keck, T. M. (2015), 'Movement litigation and unilateral disarmament: Abortion and the right to die', Law Social Inquiry 40(4), 880-907.

Scheingold, S. A. (2004), The politics of rights: Lawyers, public policy, and political change, university of Michigan Press, Ann Arbor, MI.

Soss, J. \& Schram, S. F. (2007), 'A public transformed? welfare reform as policy feedback', American Political Science Review 101(1), 111-127.

Stoddard, T. B. (1997), Why gay people should seek the right to marry, in M. Blasius \& S. Phelan, eds, 'We Are Everywhere: A Historical Sourcebook of Gay and Lesbian Politics', Routledge, New York City, NY, pp. 753-756.

Stoutenborough, J., Haider-Markel, D. P. \& Allen, M. D. (2006), 'Reassessing the impact of supreme court decisions on public opinion: Gay civil rights cases', Political Research Quarterly 59(3), 419-433.

Tadlock, B. L., Flores, A. R., Haider-Markel, D. P., Lewis, D. C., Miller, P. R. \& Taylor, J. K. (2017), 'Testing contact theory and attitudes on transgender rights', Public Opinion Quarterly 81(4), 956-972.

Tankard, M. E. \& Paluck, E. L. (2017), 'The effect of a supreme court decision regarding gay marriage on social norms and personal attitudes', Psychological Science 28(9), 13341344.

Wilcox, C., Sigelman, L. \& Cook, E. (1989), 'Some like it hot: Individual differences in responses to group feeling thermometers', Public Opinion Quarterly 53(2), 246-257. 


\section{Supplemental Information}

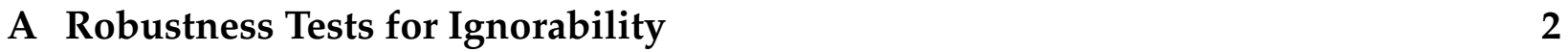

A.1 Alternate Bandwidths. . . . . . . . . . . . . . . . . . . . . . . . 2

A.2 Balance Tests . . . . . . . . . . . . . . . . . . . . . . 5

A.3 Entropy Balancing for Covariate Adjustment $\ldots \ldots \ldots$. . . . . . . . . 6

A.4 Tests for Asymmetric Attrition . . . . . . . . . . . . . . . . . . 17

A.5 Sensitivity Analysis for Unobserved Confounders . . . . . . . . . . . . 18

A.6 Results Using Ordered Probit Estimator . . . . . . . . . . . . . . . . . . . . 19

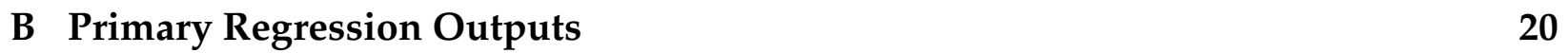

B.1 ITT Estimates for Favorability Towards Gays and Lesbians (Full Sample) . . 21

B.2 ITT Estimates for Favorability Towards Gays and Lesbians (Reigious Subsamples

B.3 ITT Estimates for Favorability Towards Gays and Lesbians (Partisan Subsamples

\begin{tabular}{|l|l|}
\hline C Robustness Tests for Excludability and Compliance & 24
\end{tabular}

C.1 Falsification Tests (Median Interview Date as Placebo Cutoff) . . . . . . . . . 24

C.2 Placebo Tests . . . . . . . . . . . . . . . . . . . . . . . . . 25

C.3 Results Using Heterosexual/Straight Subsample . . . . . . . . . . . . . . . 26 


\section{A Robustness Tests for Ignorability}

\section{A.1 Alternate Bandwidths}

Table 1: Alternate Bandwidths (Full Sample)

\begin{tabular}{lcc}
\hline & \pm 8 days & Full fieldwork for Phase 2 \\
\hline Treatment & $.012^{* *}$ & $.020^{* *}$ \\
& $(.005)$ & $(.002)$ \\
Constant & $.395^{* * *}$ & $.313^{* * *}$ \\
& $(.010)$ & $(.003)$ \\
\hline Pseudo & .080 & .078 \\
Log pseudolikelihood & -11026.29 & -19676.02 \\
$\mathrm{~N}$ & 17,092 & 141,846 \\
\hline
\end{tabular}

Table entries are probit coefficients. Robust standard errors given in parentheses. Models control for party ID, ideology, race, age, gender, education, religion, and region. Data are entropy weighted. ${ }^{*} p<.05^{* *} p<.01^{* * *} p<.001$ 
Table 2: Alternate Bandwidths (Partisan Subsamples)

\begin{tabular}{lcc}
\hline & \pm 8 days & Full fieldwork for Phase 2 \\
\hline & Democrat & \\
Treatment & $.026^{*}$ & $.022^{* * *}$ \\
& $(.008)$ & $(.004)$ \\
Constant & $.601^{* * * *}$ & $.505^{* * *}$ \\
& $(.022)$ & $(.011)$ \\
\hline Pseudo & .066 & .068 \\
Log pseudolikelihood & -3355.7728 & -4145.5039 \\
$\mathrm{~N}$ & 5,983 & 50,071 \\
\hline \multirow{4}{*}{ Treatment } & Republican & \\
& .002 & .016 \\
Constant & $(.017)$ & $(.014)$ \\
& $.165^{* * *}$ & $.100^{* * *}$ \\
Pseudo & $(.002)$ & $(.011)$ \\
Log pseudolikelihood & .037 & .037 \\
$\mathrm{~N}$ & -4006.9879 & -5068.9573 \\
& 5,528 & 45,479 \\
Treatment & Independent & \\
& -.007 & .018 \\
Constant & $(.019)$ & $(.014)$ \\
& $.415^{* * *}$ & $.309^{* * *}$ \\
Pseudo & $(.020)$ & $(.007)$ \\
Log pseudolikelihood & .055 & .059 \\
$\mathrm{~N}$ & -2959.8285 & -3809.6891 \\
\hline \multirow{4}{*}{ Treatment } & 4,638 & 38,490 \\
Constant & Something else & \\
& $.047^{* *}$ & $.033^{* *}$ \\
Pseudo & $(.022)$ & $(.010)$ \\
Log pseudolikelihood & -617.912 & $.076^{* *}$ \\
$\mathrm{~N}$ & 943 & $(.025)$ \\
\hline
\end{tabular}

Table entries are probit coefficients. Robust standard errors given in parentheses. Models control for ideology, race, age, gender, education, religion, and region. Data are entropy weighted. ${ }^{*} p<.05^{* *} p<.01^{* * *} p<.001$ 
Table 3: Alternate Bandwidths (Religious Subsamples)

\begin{tabular}{|c|c|c|}
\hline & \pm 8 days & Full fieldwork for Phase 2 \\
\hline \multicolumn{3}{|c|}{ Mainline Protestant } \\
\hline \multirow{2}{*}{ Treatment } & -.001 & .008 \\
\hline & $(.037)$ & $(.007)$ \\
\hline \multirow{2}{*}{ Constant } & $.634^{* * *}$ & $.556^{* * *}$ \\
\hline & $(.048)$ & $(.021)$ \\
\hline Pseudo & .109 & .087 \\
\hline Log pseudolikelihood & -836.256 & -1504.4243 \\
\hline $\mathrm{N}$ & 1,425 & 11,717 \\
\hline \multicolumn{3}{|c|}{ Evangelical Protestant } \\
\hline \multirow{2}{*}{ Treatment } & -.031 & .011 \\
\hline & $(.031)$ & $(.007)$ \\
\hline \multirow{2}{*}{ Constant } & $.077^{*}$ & $.037^{*}$ \\
\hline & $(.038)$ & $(.017)$ \\
\hline Pseudo & .059 & .073 \\
\hline Log pseudolikelihood & $-1219 . .024$ & -2103.1706 \\
\hline $\mathrm{N}$ & 1,723 & 14,313 \\
\hline \multicolumn{3}{|c|}{ Catholic } \\
\hline \multirow{2}{*}{ Treatment } & .027 & $.031^{* * *}$ \\
\hline & $(.021)$ & $(.005)$ \\
\hline \multirow{2}{*}{ Constant } & $.520^{* * *}$ & $.392^{* * *}$ \\
\hline & $(.022)$ & $(.008)$ \\
\hline Pseudo & .030 & .037 \\
\hline Log pseudolikelihood & -2664.2425 & -4238.1665 \\
\hline $\mathrm{N}$ & 3,701 & 29,904 \\
\hline \multicolumn{3}{|c|}{ Other Christian } \\
\hline \multirow{2}{*}{ Treatment } & -.003 & .017 \\
\hline & $(.020)$ & $(.014)$ \\
\hline \multirow{2}{*}{ Constant } & $.179^{* * *}$ & $.111^{* * *}$ \\
\hline & $(.021)$ & $(.008)$ \\
\hline Pseudo & .038 & .040 \\
\hline Log pseudolikelihood & -2850.4275 & -5023.4604 \\
\hline $\mathrm{N}$ & 3,997 & 33,600 \\
\hline \multicolumn{3}{|c|}{ Non-Christian } \\
\hline \multirow{2}{*}{ Treatment } & .024 & .009 \\
\hline & $(.031)$ & $(.007)$ \\
\hline \multirow{2}{*}{ Constant } & $.321^{* * *}$ & $274^{* * *}$ \\
\hline & $(.031)$ & $(.011)$ \\
\hline Pseudo & .067 & .063 \\
\hline Log pseudolikelihood & -1268.002 & -2125.5386 \\
\hline $\mathrm{N}$ & 1,834 & 14,775 \\
\hline \multicolumn{3}{|c|}{ Unaffiliated } \\
\hline \multirow{2}{*}{ Treatment } & $.032 *$ & $.025^{* * *}$ \\
\hline & $(.011)$ & $(.005)$ \\
\hline \multirow{2}{*}{ Constant } & $.558^{* * *}$ & $.452^{* * *}$ \\
\hline & $(.023)$ & $(.008)$ \\
\hline Pseudo & .092 & .098 \\
\hline Log pseudolikelihood & -2463.9445 & -4482.547 \\
\hline $\mathrm{N}$ & 4,432 & 37,537 \\
\hline
\end{tabular}




\section{A.2 Balance Tests}

Table 1: Covariate Differences Between Treatment and Control Groups

\begin{tabular}{lccc}
\hline & Pre-announcement & Post-announcement & $\mathrm{p}$ \\
\hline Party ID & 3.837 & 3.865 & n.s. \\
Ideology (conservative) & 3.028 & 3.304 & n.s. \\
White & $63.4 \%$ & $64.8 \%$ & n.s. \\
Age & 47.144 years & 47.158 years & n.s. \\
Male & $48.3 \%$ & $47.1 \%$ & n.s. \\
Education & 6.135 & 6.173 & n.s. \\
Evangelical Protestant & $9.2 \%$ & $9.8 \%$ & n.s. \\
Catholic & $23.1 \%$ & $22.9 \%$ & n.s. \\
Other Christian & $21.5 \%$ & $21.3 \%$ & n.s. \\
Non-Christian & $11.2 \%$ & $11.1 \%$ & n.s. \\
Unaffiliated & $25.4 \%$ & $26.2 \%$ & n.s. \\
South & $35.8 \%$ & $38 \%$ & n.s. \\
\hline
\end{tabular}

Notes: Data are weighted using Nationscape general population weights. Asterisks indicate a statistically significant mean difference between treatment and control groups $\left({ }^{*} \mathrm{p}\right.$ i.05** p j.01*** p i.001). 


\section{A.3 Entropy Balancing for Covariate Adjustment}

Table 1: Before Weighting (Full Sample)

\begin{tabular}{lcccccc}
\hline & Mean & $\begin{array}{c}\text { Treatment } \\
\text { variance }\end{array}$ & Skewness & Mean & $\begin{array}{c}\text { Control } \\
\text { variance }\end{array}$ & Skewness \\
\hline Party ID & 3.938 & 5.037 & .059 & 3.913 & 4.976 & .076 \\
Ideology (conservative) & 3.016 & 1.226 & -.029 & 3.027 & 1.185 & -.040 \\
White & $68.1 \%$ & .217 & -.776 & $69.9 \%$ & .214 & -.876 \\
Age & 45.09 years & 269.4 & .193 & 45.84 years & 275.2 & .134 \\
Male & $45.49 \%$ & .248 & .181 & $44.46 \%$ & .247 & .214 \\
Education & 6.524 & 5.047 & .038 & 6.515 & 4.904 & .036 \\
Evangelical Protestant & $10.2 \%$ & .091 & 2.626 & $10.1 \%$ & .090 & 2.648 \\
Catholic & $21.3 \%$ & .167 & 1.399 & $21.8 \%$ & .170 & 1.363 \\
Other Christian & $23.6 \%$ & .180 & 1.242 & $22.7 \%$ & .175 & 1.299 \\
Non-Christian & $10.7 \%$ & .095 & 2.537 & $10.6 \%$ & .095 & 2.545 \\
Unaffiliated & $25.9 \%$ & .192 & 1.095 & $25.8 \%$ & .191 & 1.105 \\
South & $37.73 \%$ & .235 & .506 & $37.1 \%$ & .233 & .534 \\
\hline
\end{tabular}

Table 2: After Weighting (Full Sample)

\begin{tabular}{lcccccc}
\hline & Mean & $\begin{array}{c}\text { Treatment } \\
\text { variance }\end{array}$ & Skewness & Mean & $\begin{array}{c}\text { Control } \\
\text { variance }\end{array}$ & Skewness \\
\hline Party ID & 3.938 & 5.037 & .059 & 3.938 & 4.976 & .061 \\
Ideology (conservative) & 3.016 & 1.226 & -.029 & 3.016 & 1.192 & -.039 \\
White & $68.1 \%$ & .217 & -.776 & $68.1 \%$ & .217 & -.776 \\
Age & 45.09 years & 269.4 & .193 & 45.09 years & .272 & .184 \\
Male & $45.49 \%$ & .248 & .181 & $45.48 \%$ & .248 & .181 \\
Education & 6.524 & 5.047 & .038 & 6.524 & 4.938 & .032 \\
Evangelical Protestant & $10.2 \%$ & .091 & 2.626 & $10.2 \%$ & .091 & 2.626 \\
Catholic & $21.3 \%$ & .167 & 1.399 & $21.3 \%$ & .167 & 1.399 \\
Other Christian & $23.6 \%$ & .180 & 1.242 & $23.6 \%$ & .180 & 1.243 \\
Non-Christian & $10.7 \%$ & .095 & 2.537 & $10.7 \%$ & .095 & 2.538 \\
Unaffiliated & $25.9 \%$ & .192 & 1.095 & $25.9 \%$ & .192 & 1.095 \\
South & $37.73 \%$ & .235 & .506 & $37.7 \%$ & .235 & .506 \\
\hline
\end{tabular}


Table 3: Before Weighting (Mainline Protestant Subsample)

\begin{tabular}{lcccccc}
\hline & Mean & $\begin{array}{l}\text { Treatment } \\
\text { variance }\end{array}$ & Skewness & Mean & $\begin{array}{c}\text { Control } \\
\text { variancce }\end{array}$ & Skewness \\
\hline Party ID & 4.006 & 5.293 & -.030 & 3.934 & 5.077 & -.008 \\
Ideology (conservative) & 3.122 & 1.056 & -.041 & 3.149 & 1.045 & -.127 \\
White & $85.2 \%$ & .126 & -1.983 & $84 \%$ & .134 & -1.859 \\
Age & 56.67 years & 232.8 & -.648 & 56.51 years & .241 & -.699 \\
Male & $45.8 \%$ & .248 & .168 & $44.7 \%$ & .247 & .210 \\
Education & 7.082 & 4.03 & -.204 & 6.969 & 4.17 & -.230 \\
South & $37.4 \%$ & .234 & .519 & $36.3 \%$ & .231 & .568 \\
\hline
\end{tabular}

Table 4: After Weighting (Mainline Protestant Subsample)

\begin{tabular}{lcccccc}
\hline & Mean & $\begin{array}{c}\text { Treatment } \\
\text { variance }\end{array}$ & Skewness & Mean & $\begin{array}{c}\text { Control } \\
\text { variance }\end{array}$ & Skewness \\
\hline Party ID & 4.006 & 5.293 & -.030 & 4.006 & 5.069 & -.064 \\
Ideology (conservative) & 3.122 & 1.056 & -.041 & 3.122 & 1.052 & -.133 \\
White & $85.2 \%$ & .126 & -1.983 & $85.2 \%$ & .126 & -1.983 \\
Age & 56.67 years & 232.8 & -.648 & 56.67 years & 237.3 & -.697 \\
Male & $45.8 \%$ & .248 & .168 & $45.8 \%$ & .248 & .168 \\
Education & 7.082 & 4.03 & -.204 & 7.083 & 4.104 & -.269 \\
South & $37.4 \%$ & .234 & .519 & $37.4 \%$ & .234 & .519 \\
\hline
\end{tabular}


Table 5: Before Weighting (Evangelical Protestant Subsample)

\begin{tabular}{lcccccc}
\hline & Mean & $\begin{array}{c}\text { Treatment } \\
\text { variance }\end{array}$ & Skewness & Mean & $\begin{array}{c}\text { Control } \\
\text { variance }\end{array}$ & Skewness \\
\hline Party ID & 4.921 & 5.131 & -.682 & 4.937 & 5.194 & -.670 \\
Ideology (conservative) & 3.624 & 1.313 & -.554 & 3.652 & 1.357 & -.617 \\
White & $76.1 \%$ & .181 & -1.226 & $76.1 \%$ & .162 & -1.468 \\
Age & 52.85 years & 252.4 & -.321 & 52.87 years & 252.1 & -.310 \\
Male & $44.5 \%$ & .247 & .219 & $45.4 \%$ & .246 & .184 \\
Education & 6.838 & 4.327 & -.107 & 6.788 & 4.407 & -.045 \\
South & $50.4 \%$ & .250 & -.016 & $47.2 \%$ & .249 & .109 \\
\hline
\end{tabular}

Table 6: After Weighting (Evangelical Protestant Subsample)

\begin{tabular}{lcccccc}
\hline & Mean & $\begin{array}{c}\text { Treatment } \\
\text { variance }\end{array}$ & Skewness & Mean & $\begin{array}{c}\text { Control } \\
\text { variance }\end{array}$ & Skewness \\
\hline Party ID & 4.921 & 5.131 & -.682 & 4.921 & 5.261 & -.658 \\
Ideology (conservative) & 3.624 & 1.313 & -.554 & 3.624 & 1.387 & -.602 \\
White & $76.1 \%$ & .181 & -1.226 & $76.1 \%$ & .181 & -1.226 \\
Age & 52.85 years & 252.4 & -.321 & 52.85 years & 253 & -.313 \\
Male & $44.5 \%$ & .247 & .219 & $44.55 \%$ & .247 & .219 \\
Education & 6.838 & 4.327 & -.107 & 6.838 & 4.42 & -.067 \\
South & $50.4 \%$ & .250 & -.016 & $50.4 \%$ & .250 & -.016 \\
\hline
\end{tabular}


Table 7: Before Weighting (Catholic Subsample)

\begin{tabular}{lccccc|c}
\hline & Mean & $\begin{array}{c}\text { Treatment } \\
\text { variance }\end{array}$ & Skewness & Mean & $\begin{array}{c}\text { Control } \\
\text { variance }\end{array}$ & Skewness \\
\hline Party ID & 4.012 & 5.318 & .012 & 3.966 & 5.369 & .043 \\
Ideology (conservative) & 3.123 & 1.152 & -.067 & 3.086 & 1.111 & -.021 \\
White & $66.1 \%$ & .224 & -.681 & $67.3 \%$ & .22 & -.739 \\
Age & 46.93 years & 276.3 & .091 & 47.74 years & 277.7 & .026 \\
Male & $46.2 \%$ & .248 & .151 & $47.3 \%$ & .249 & .107 \\
Education & 6.75 & 4.953 & -.113 & 6.815 & 4.77 & -.116 \\
South & $29.6 \%$ & .208 & .890 & $31 . \%$ & .214 & .816 \\
\hline
\end{tabular}

Table 8: After Weighting (Catholic Subsample)

\begin{tabular}{lcccccc}
\hline & Mean & $\begin{array}{c}\text { Treatment } \\
\text { variance }\end{array}$ & Skewness & Mean & $\begin{array}{c}\text { Control } \\
\text { variance }\end{array}$ & Skewness \\
\hline Party ID & 4.012 & 5.318 & .012 & 4.012 & 5.345 & .014 \\
Ideology (conservative) & 3.123 & 1.152 & -.067 & 3.123 & 1.106 & -.026 \\
White & $66.1 \%$ & .224 & -.681 & $66.1 \%$ & .224 & -.681 \\
Age & 46.93 years & 276.3 & .091 & $46.93 \%$ & 278.4 & .071 \\
Male & $46.2 \%$ & .248 & .151 & $46.2 \%$ & .248 & .151 \\
Education & 6.75 & 4.953 & -.113 & 6.75 & 4.794 & -.092 \\
South & $29.6 \%$ & .208 & .890 & $29.6 \%$ & .208 & .890 \\
\hline
\end{tabular}


Table 9: Before Weighting (Other Christian Subsample)

\begin{tabular}{lcccccc}
\hline & Mean & $\begin{array}{c}\text { Treatment } \\
\text { variance }\end{array}$ & Skewness & Mean & $\begin{array}{c}\text { Control } \\
\text { variance }\end{array}$ & Skewness \\
\hline Party ID & 4.302 & 5.225 & -.181 & 4.298 & 5.049 & -.181 \\
Ideology (conservative) & 3.115 & 1.242 & -.120 & 3.133 & 1.123 & -.140 \\
White & $64.1 \%$ & .23 & -.590 & $64.7 \%$ & .228 & -.615 \\
Age & 41.13 years & 196.3 & .362 & 41.76 years & 208.5 & .277 \\
Male & $43.2 \%$ & .245 & .272 & $41.8 \%$ & .243 & .329 \\
Education & 6.309 & 5.525 & .218 & 6.275 & 5.127 & .219 \\
South & $44.5 \%$ & .247 & .220 & $31.1 \%$ & .245 & .281 \\
\hline
\end{tabular}

Table 10: After Weighting (Other Christian Subsample)

\begin{tabular}{lccc|ccc}
\hline & Mean & $\begin{array}{c}\text { Treatment } \\
\text { variance }\end{array}$ & Skewness & Mean & $\begin{array}{c}\text { Control } \\
\text { variance }\end{array}$ & Skewness \\
\hline Party ID & 4.302 & 5.225 & -.181 & 4.302 & 5.056 & -.182 \\
Ideology (conservative) & 3.115 & 1.242 & -.120 & 3.115 & 1.134 & -.137 \\
White & $64.1 \%$ & .23 & -.590 & $64.1 \%$ & .23 & -.590 \\
Age & 41.13 years & 196.3 & .362 & 41.13 years & 204.3 & .314 \\
Male & $43.2 \%$ & .245 & .272 & $43.2 \%$ & .242 & .272 \\
Education & 6.309 & 5.525 & .218 & 6.309 & 5.193 & .204 \\
South & $44.5 \%$ & .247 & .220 & $44.5 \%$ & .247 & .220 \\
\hline
\end{tabular}


Table 11: Before Weighing (Non-Christian Subsample)

\begin{tabular}{lcccccc}
\hline & Mean & $\begin{array}{c}\text { Treatment } \\
\text { variance }\end{array}$ & Skewness & Mean & $\begin{array}{c}\text { Control } \\
\text { variance }\end{array}$ & Skewness \\
\hline Party ID & 3.505 & 4.665 & .336 & 3.501 & 4.707 & .346 \\
Ideology (conservative) & 2.766 & 1.179 & .104 & 2.861 & 1.259 & .084 \\
White & $61.4 \%$ & .237 & -.469 & $59.7 \%$ & .240 & -.397 \\
Age & 44.6 years & 274.9 & .189 & 45.49 years & 291.7 & .223 \\
Male & $50.1 \%$ & .250 & -.003 & $47.7 \%$ & .249 & -.088 \\
Education & 6.727 & 5.684 & -.027 & 6.745 & 5.473 & -.055 \\
South & $36.8 \%$ & .232 & .544 & $36.4 \%$ & .231 & .565 \\
\hline
\end{tabular}

Table 12: After Weighing (Non-Christian Subsample)

\begin{tabular}{lcccccc}
\hline & Mean & $\begin{array}{c}\text { Treatment } \\
\text { variance }\end{array}$ & Skewness & Mean & $\begin{array}{c}\text { Control } \\
\text { variance }\end{array}$ & Skewness \\
\hline Party ID & 3.505 & 4.665 & .336 & 3.505 & 4.741 & .350 \\
Ideology (conservative) & 2.766 & 1.179 & .104 & 2.766 & 1.261 & .124 \\
White & $61.4 \%$ & .237 & -.469 & $61.4 \%$ & .237 & -.469 \\
Age & 44.6 years & 274.9 & .189 & 44.6 years & 286.5 & .283 \\
Male & $50.1 \%$ & .250 & -.003 & $50.1 \%$ & .250 & -.003 \\
Education & 6.727 & 5.684 & -.027 & 6.727 & 5.536 & -.048 \\
South & $36.8 \%$ & .232 & .544 & $36.8 \%$ & .232 & .544 \\
\hline
\end{tabular}


Table 13: Before Weighting (Unaffiiated Subsample)

\begin{tabular}{lcccccc}
\hline & Mean & $\begin{array}{c}\text { Treatment } \\
\text { variance }\end{array}$ & Skewness & Mean & $\begin{array}{c}\text { Control } \\
\text { variance }\end{array}$ & Skewness \\
\hline Party ID & 3.318 & 3.712 & .431 & 3.321 & 3.604 & .414 \\
Ideology (conservative) & 2.668 & .996 & .028 & 2.676 & .955 & -.031 \\
White & $67.5 \%$ & .219 & -.749 & $66.8 \%$ & .215 & -.803 \\
Age & 40.69 years & 244.4 & .467 & 42.05 years & 260.4 & .376 \\
Male & $45.2 \%$ & .247 & .189 & $45.1 \%$ & .247 & .196 \\
Education & 6.152 & 4.656 & .168 & 6.182 & 4.686 & .155 \\
South & $33.6 \%$ & .223 & .692 & $33 \%$ & .221 & .719 \\
\hline
\end{tabular}

Table 14: After Weighting (Unaffiiated Subsample)

\begin{tabular}{lllllll}
\hline & Mean & $\begin{array}{l}\text { Treatment } \\
\text { variance }\end{array}$ & Skewness & Mean & $\begin{array}{l}\text { Control } \\
\text { variance }\end{array}$ & Skewness \\
\hline Party ID & 3.318 & 3.712 & .431 & 3.318 & 3.571 & .417 \\
Ideology (conservative) & 2.668 & .996 & .028 & 2.668 & .949 & -.035 \\
White & $67.5 \%$ & .219 & -.749 & $67.5 \%$ & .219 & -.749 \\
Age & 40.69 years & 244.4 & .467 & 40.69 years & 251.1 & .470 \\
Male & $45.2 \%$ & .247 & .189 & $45.2 \%$ & .247 & .189 \\
Education & 6.152 & 4.656 & .168 & 6.152 & 4.7 & .165 \\
South & $33.6 \%$ & .223 & .692 & $33.6 \%$ & .223 & .692 \\
\hline
\end{tabular}


Table 15: Before Weighting (Democrat Subsample)

\begin{tabular}{lcccccc}
\hline & Mean & $\begin{array}{c}\text { Treatment } \\
\text { variance }\end{array}$ & Skewness & Mean & $\begin{array}{c}\text { Control } \\
\text { variance }\end{array}$ & Skewness \\
\hline Ideology (conservative) & 2.396 & .893 & .257 & 2.408 & .903 & .229 \\
White & $56 \%$ & .246 & -.242 & $57.3 \%$ & .246 & -.298 \\
Age & 44.48 years & 280.9 & .177 & 45.5 years & .291 & .120 \\
Male & $37.9 \%$ & .235 & .498 & $38.2 \%$ & .236 & .483 \\
Education & 6.654 & 4.894 & -.056 & 6.678 & 4.766 & -.058 \\
Evangelical Protestant & $6.7 \%$ & .062 & 3.451 & $6.7 \%$ & .062 & 3.455 \\
Catholic & $22.2 \%$ & .173 & 1.334 & $23.4 \%$ & .179 & 1.253 \\
Other Christian & $20.6 \%$ & .163 & 1.452 & $19 \%$ & .154 & 1.575 \\
Non-Christian & $12.4 \%$ & .109 & 2.269 & $12.6 \%$ & .110 & 2.254 \\
Unaffiliated & $29.5 \%$ & .208 & .896 & $28.6 \%$ & .204 & .944 \\
South & $35.3 \%$ & .228 & .613 & $34 \%$ & .224 & .672 \\
\hline
\end{tabular}

Table 16: After Weighting (Democrat Subsample)

\begin{tabular}{lcccccc}
\hline & Mean & $\begin{array}{c}\text { Treatment } \\
\text { variance }\end{array}$ & Skewness & Mean & $\begin{array}{c}\text { Control } \\
\text { variance }\end{array}$ & Skewness \\
\hline Ideology (conservative) & 2.396 & .893 & .257 & 2.396 & .906 & .232 \\
White & $56 \%$ & .246 & -.242 & $56 \%$ & .246 & -.243 \\
Age & 44.48 years & 280.9 & .177 & 44.8 years & 287.6 & .185 \\
Male & $37.9 \%$ & .235 & .498 & $37.9 \%$ & .235 & .498 \\
Education & 6.654 & 4.894 & -.056 & 6.654 & 4.786 & -.050 \\
Evangelical Protestant & $6.7 \%$ & .062 & 3.451 & $6.7 \%$ & .062 & 3.451 \\
Catholic & $22.2 \%$ & .173 & 1.334 & $22.2 \%$ & .173 & 1.333 \\
Other Christian & $20.6 \%$ & .163 & 1.452 & $20.6 \%$ & .163 & 1.453 \\
Non-Christian & $12.4 \%$ & .109 & 2.269 & $12.4 \%$ & .109 & 2.269 \\
Unaffiliated & $29.5 \%$ & .208 & .896 & $29.5 \%$ & .208 & .896 \\
South & $35.3 \%$ & .228 & .613 & $35.3 \%$ & .228 & .613 \\
\hline
\end{tabular}


Table 17: Before Weighting (Republican Subsample)

\begin{tabular}{lcccccc}
\hline & Mean & $\begin{array}{c}\text { Treatment } \\
\text { variance }\end{array}$ & Skewness & Mean & $\begin{array}{c}\text { Control } \\
\text { variance }\end{array}$ & Skewness \\
\hline Ideology (conservative) & 3.702 & 1.225 & -.739 & 3.695 & 1.217 & -.710 \\
White & $83.5 \%$ & .137 & -1.008 & $83.4 \%$ & .138 & -1.976 \\
Age & 47.89 years & 246.9 & .12 & 48.68 years & 247.9 & .024 \\
Male & $53.5 \%$ & .248 & -.143 & $52.7 \%$ & .249 & .110 \\
Education & 6.808 & 5.136 & -.029 & 6.724 & 5.007 & -.021 \\
Evangelical Protestant & $16.9 \%$ & .140 & 1.762 & $17.2 \%$ & .142 & 1.733 \\
Catholic & $23.8 \%$ & .181 & 1.23 & $24.1 \%$ & .183 & 1.206 \\
Other Christian & $29 \%$ & .205 & .925 & $27.6 \%$ & .200 & .997 \\
Non-Christian & $7.5 \%$ & .070 & 3.206 & $8.1 \%$ & .074 & 3.06 \\
Unaffiliated & $13.6 \%$ & .118 & 2.115 & $13 \%$ & .113 & 2.191 \\
South & $41 \%$ & .242 & .364 & $40.6 \%$ & .241 & .380 \\
\hline
\end{tabular}

Table 18: After Weighting (Republican Subsample)

\begin{tabular}{lllllll}
\hline & Mean & $\begin{array}{l}\text { Treatment } \\
\text { variance }\end{array}$ & Skewness & Mean & $\begin{array}{l}\text { Control } \\
\text { variance }\end{array}$ & Skewness \\
\hline Ideology (conservative) & 3.702 & 1.225 & -.739 & 3.702 & 1.199 & -.733 \\
White & $83.5 \%$ & .137 & -1.008 & $83.5 \%$ & .137 & -1.008 \\
Age & 47.89 years & 246.9 & .12 & 47.89 years & 244.8 & .078 \\
Male & $53.5 \%$ & .248 & -.143 & $53.5 \%$ & .248 & -.143 \\
Education & 6.808 & 5.136 & -.029 & 6.808 & 5.022 & -.059 \\
Evangelical Protestant & $16.9 \%$ & .140 & 1.762 & $16.9 \%$ & .140 & 1.782 \\
Catholic & $23.8 \%$ & .181 & 1.23 & $23.8 \%$ & .181 & 1.23 \\
Other Christian & $29 \%$ & .205 & .925 & $29 \%$ & .205 & .926 \\
Non-Christian & $7.5 \%$ & .070 & 3.206 & $7.5 \%$ & .070 & 3.206 \\
Unaffiliated & $13.6 \%$ & .118 & 2.115 & $13.6 \%$ & .118 & 2.115 \\
South & $41 \%$ & .242 & .364 & $41 \%$ & .364 & .242 \\
\hline
\end{tabular}


Table 19: Before Weighting (Independent Subsample)

\begin{tabular}{lcccccc}
\hline & Mean & $\begin{array}{c}\text { Treatment } \\
\text { variance }\end{array}$ & Skewness & Mean & $\begin{array}{c}\text { Control } \\
\text { variance }\end{array}$ & Skewness \\
\hline Ideology (conservative) & 2.905 & .706 & -.177 & 3.038 & .650 & -.075 \\
White & $66.2 \%$ & .223 & -.684 & $68.4 \%$ & .216 & -.792 \\
Age & 43.47 years & 275.6 & .298 & 44.43 years & 286.3 & .227 \\
Male & $46 \%$ & .248 & .158 & $46 \%$ & .248 & .157 \\
Education & 6.201 & 4.927 & .147 & 6.288 & 4.849 & .134 \\
Evangelical Protestant & $7.7 \%$ & .071 & 3.153 & $7 \%$ & .065 & 3.342 \\
Catholic & $18.6 \%$ & .151 & 1.623 & $18.9 \%$ & .153 & 1.584 \\
Other Christian & $20.9 \%$ & .165 & 1.427 & $20.9 \%$ & .166 & 1.429 \\
Non-Christian & $10.8 \%$ & .096 & 2.521 & $10.4 \%$ & .093 & 2.591 \\
Unaffiliated & $34 \%$ & .224 & .675 & $34.5 \%$ & .226 & .648 \\
South & $36.8 \%$ & .232 & .546 & $36.1 \%$ & .230 & .578 \\
\hline
\end{tabular}

Table 20: After Weighting (Independent Subsample)

\begin{tabular}{lcccccc}
\hline & Mean & $\begin{array}{c}\text { Treatment } \\
\text { variance }\end{array}$ & Skewness & Mean & $\begin{array}{c}\text { Control } \\
\text { variance }\end{array}$ & Skewness \\
\hline Ideology (conservative) & 2.905 & .706 & -.177 & 2.905 & .655 & -.147 \\
White & $66.2 \%$ & .223 & -.684 & $66.2 \%$ & .223 & -.684 \\
Age & 43.47 years & 275.6 & .298 & 43.47 years & 283.5 & .286 \\
Male & $46 \%$ & .248 & .158 & $46 \%$ & .248 & .165 \\
Education & 6.201 & 4.927 & .147 & 6.201 & 4.834 & .170 \\
Evangelical Protestant & $7.7 \%$ & .071 & 3.153 & $7.7 \%$ & .071 & 3.153 \\
Catholic & $18.6 \%$ & .151 & 1.623 & $18.6 \%$ & .151 & 1.613 \\
Other Christian & $20.9 \%$ & .165 & 1.427 & $20.9 \%$ & .165 & 1.427 \\
Non-Christian & $10.8 \%$ & .096 & 2.521 & $10.8 \%$ & .096 & 2.521 \\
Unaffiliated & $34 \%$ & .224 & .675 & $34 \%$ & .224 & .675 \\
South & $36.8 \%$ & .232 & .546 & $36.8 \%$ & .232 & .546 \\
\hline
\end{tabular}


Table 21: Before Weighting ("Something Else" Subsample)

\begin{tabular}{lcccccc}
\hline & Mean & $\begin{array}{c}\text { Treatment } \\
\text { variance }\end{array}$ & Skewness & Mean & $\begin{array}{l}\text { Control } \\
\text { variance }\end{array}$ & Skewness \\
\hline Ideology (conservative) & 3.026 & .689 & -.307 & 3.017 & .652 & -.206 \\
White & $62.5 \%$ & .234 & -.518 & $61 \%$ & .238 & -.451 \\
Age & 40.28 years & 214.9 & .447 & 41.5 years & 224.9 & .489 \\
Male & $42.8 \%$ & .245 & .29 & $39.8 \%$ & .239 & .415 \\
Education & 5.619 & 4.171 & .414 & 5.769 & 4.278 & .314 \\
Evangelical Protestant & $4.5 \%$ & .043 & 4.336 & $4.1 \%$ & .039 & 4.59 \\
Catholic & $14.4 \%$ & .123 & 2.021 & $12.3 \%$ & .108 & 2.286 \\
Other Christian & $23.8 \%$ & .182 & 1.225 & $25.4 \%$ & .189 & 1.127 \\
Non-Christian & $17.8 \%$ & .146 & 1.641 & $15.9 \%$ & .134 & 1.862 \\
Unaffiliated & $36.6 \%$ & .232 & .553 & $37.1 \%$ & .233 & .534 \\
South & $37.7 \%$ & .235 & .504 & $38.2 \%$ & .236 & .481 \\
\hline
\end{tabular}

Table 22: After Weighting ("Something Else" Subsample)

\begin{tabular}{lcccccc}
\hline & Mean & $\begin{array}{c}\text { Treatment } \\
\text { variance }\end{array}$ & Skewness & Mean & $\begin{array}{c}\text { Control } \\
\text { variance }\end{array}$ & Skewness \\
\hline Ideology (conservative) & 3.026 & .689 & -.307 & 3.026 & .643 & -.146 \\
White & $62.5 \%$ & .234 & -.518 & $62.5 \%$ & .234 & -.518 \\
Age & 40.28 years & 214.9 & .447 & 40.28 years & 217.4 & .51 \\
Male & $42.8 \%$ & .245 & .29 & $42.8 \%$ & .245 & .291 \\
Education & 5.619 & 4.171 & .414 & 5.619 & 4.143 & .387 \\
Evangelical Protestant & $4.5 \%$ & .043 & 4.336 & $4.5 \%$ & .043 & 4.439 \\
Catholic & $14.4 \%$ & .123 & 2.021 & $14.4 \%$ & .123 & 2.203 \\
Other Christian & $23.8 \%$ & .182 & 1.225 & $23.8 \%$ & .182 & 1.225 \\
Non-Christian & $17.8 \%$ & .146 & 1.641 & $17.8 \%$ & .146 & 1.683 \\
Unaffiliated & $36.6 \%$ & .232 & .553 & $36.6 \%$ & .232 & .554 \\
South & $37.7 \%$ & .235 & .504 & $37.7 \%$ & .235 & .503 \\
\hline
\end{tabular}




\section{A.4 Tests for Asymmetric Attrition}

Table 1: Probit Estimates for Willingness to Respond to LGBT Favorability Measure

\begin{tabular}{lc}
\hline & $\begin{array}{c}\text { Willingness to } \\
\text { respond }\end{array}$ \\
\hline Treatment & -.007 \\
Party ID & $. .019)$ \\
& $-.079^{* *}$ \\
Ideology (Conservative) & $. .025)$ \\
& $(.024)$ \\
White & $.116^{* * *}$ \\
& $(.020)$ \\
Age & -.002 \\
& $(021)$ \\
Male & $-.067^{* *}$ \\
& $(.020)$ \\
Education & $.073^{* *}$ \\
& $(.021)$ \\
Evangelical Protestant & .011 \\
& $(.030)$ \\
Catholic & .022 \\
& $(.035)$ \\
Other Christian & -.030 \\
& $(.035)$ \\
Non-Christian & $-.064^{*}$ \\
& $(.027)$ \\
Unaffiliated & .038 \\
& $(.038)$ \\
South & .030 \\
Constant & $(.038)$ \\
& $2.280^{* * *}$ \\
Pseudo & $(.021)$ \\
$\mathrm{N}$ & .023 \\
& -2516.4817 \\
Tog pseudolikelihood & 30,875 \\
\hline
\end{tabular}

Table entries are probit coefficients. Robust standard errors given in parentheses. Data are entropy weighted. ${ }^{*} p<.05^{* *} p<.01^{* * *} p<.001$ 


\section{A.5 Sensitivity Analysis for Unobserved Confounders}

Table 1: Estimates of the Percentage of Bias Necessary to Invalidate the Inference for the Effect of Treatment on Favorability Towards LGBT Individuals

\begin{tabular}{|c|c|c|}
\hline Model & APE & $\begin{array}{c}\% \text { of bias } \\
\text { necessary to } \\
\text { invalidate } \\
\text { inference }\end{array}$ \\
\hline Full sample & $\begin{array}{l}.008^{* * *} \\
(.002)\end{array}$ & $38.23 \%$ \\
\hline \multicolumn{3}{|c|}{ Religious subsamples } \\
\hline Mainline Protestant & $\begin{array}{c}.003 \\
(.008)\end{array}$ & $76.46 \%$ \\
\hline Evangelical Protestant & $\begin{array}{c}-.001 \\
(.008)\end{array}$ & $94.31 \%$ \\
\hline Catholic & $\begin{array}{c}.011 \\
(.005)\end{array}$ & $.56 \%$ \\
\hline Other Christian & $\begin{array}{c}.007 \\
(.005)\end{array}$ & $31.42 \%$ \\
\hline Non-Christian & $\begin{array}{c}.005 \\
(.008)\end{array}$ & $68.28 \%$ \\
\hline Unaffiliated & $\begin{array}{l}.012^{* *} \\
(.004)\end{array}$ & $27.99 \%$ \\
\hline \multicolumn{3}{|c|}{ Partisan subsamples } \\
\hline Democrat & $\begin{array}{l}.011^{*} \\
(.004)\end{array}$ & $29.82 \%$ \\
\hline Republican & $\begin{array}{c}.004 \\
(.004)\end{array}$ & $50.35 \%$ \\
\hline Independent & $\begin{array}{c}.002 \\
(.005)\end{array}$ & $75.69 \%$ \\
\hline Something else & $\begin{array}{l}.025^{*} \\
(.011)\end{array}$ & $11.22 \%$ \\
\hline
\end{tabular}

Notes: Table entries are the average marginal effect of the treatment in each model. Standard errors given in parentheses. Models control for party ID (with exception of partisan subsamples), ideology, race, age, gender, education, religion (with exception of religious subsamples), and region. Data are entropy weighted. ${ }^{*} p<.05^{* *} p<.01{ }^{* * *} p$ $<.001$. 


\section{A.6 Results Using Ordered Probit Estimator}

Table 1: ITT Estimates for Favorability Towards LGBT Individuals (Ordered Probit)

\begin{tabular}{|c|c|c|}
\hline & Simple & With controls \\
\hline Treatment & $\begin{array}{l}.012^{*} \\
(.006)\end{array}$ & $\begin{array}{l}.013^{*} \\
(.006)\end{array}$ \\
\hline Party ID & 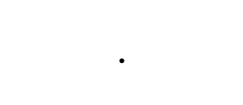 & $\begin{array}{c}-.180^{* * * *} \\
(.008)\end{array}$ \\
\hline Ideology (conservative) & . & $\begin{array}{c}-.191^{* * * *} \\
(.008)\end{array}$ \\
\hline White & . & $\begin{array}{l}.089^{* * * *} \\
(.006)\end{array}$ \\
\hline Age & . & $\begin{array}{c}-.118^{* * * *} \\
(.006)\end{array}$ \\
\hline Male & - & $\begin{array}{l}-.135^{* * *} \\
(.006)\end{array}$ \\
\hline Education & . & $\begin{array}{c}-.068^{* * *} \\
(.006)\end{array}$ \\
\hline Evangelical Protestant & . & $\begin{array}{c}-.120^{* * *} \\
(.008)\end{array}$ \\
\hline Catholic & . & $\begin{array}{l}.007 \\
(.009)\end{array}$ \\
\hline Other Christian & . & $\begin{array}{c}-.110^{* * * *} \\
(.010)\end{array}$ \\
\hline Non-Christian & . & $\begin{array}{c}-.040^{* * * *} \\
(.008)\end{array}$ \\
\hline Unaffiliated & . & $\begin{array}{l}.045^{* * *} \\
(.010)\end{array}$ \\
\hline South & . & $\begin{array}{l}-.005 \\
(.006) \\
\end{array}$ \\
\hline /cut1 & $-1.234[.009]$ & $-1.355[.010]$ \\
\hline /cut2 & $-.726[.007]$ & $-.798[.008]$ \\
\hline /cut3 & $-.345[.007]$ & $-.377[.007]$ \\
\hline /cut4 & $.446[. .007]$ & $.490[.007]$ \\
\hline Pseudo & .001 & .053 \\
\hline $\begin{array}{l}\text { Log pseudolikelihood } \\
\text { N }\end{array}$ & $\begin{array}{c}-48322.453 \\
30,489\end{array}$ & $\begin{array}{c}-45729.234 \\
30,489\end{array}$ \\
\hline
\end{tabular}

Notes: Table entries are ordered probit coefficients. Robust standard errors given in parentheses. Data are entropy weighted. ${ }^{*} p$ $<.05^{* *} p<.01^{* * *} p<.001$. 
B Primary Regression Outputs 


\section{B.1 ITT Estimates for Favorability Towards Gays and Lesbians (Full Sample)}

Table 1: ITT Estimates for Favorability Towards Gays and Lesbians (Full Sample)

\begin{tabular}{|c|c|c|}
\hline & Simple & With controls \\
\hline Treatment & $\begin{array}{l}.021^{* *} \\
(.007)\end{array}$ & $\begin{array}{l}.024^{* *} \\
(.007)\end{array}$ \\
\hline Party ID & 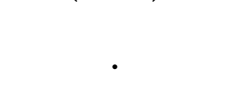 & $\begin{array}{l}-.188^{* * * *} \\
(.009)\end{array}$ \\
\hline Ideology (conservative) & . & $\begin{array}{c}-.178^{* * * *} \\
(.009)\end{array}$ \\
\hline White & . & $\begin{array}{l}.091^{* * *} \\
(.008)\end{array}$ \\
\hline Age & & $\begin{array}{c}-.074^{* * * *} \\
(.008)\end{array}$ \\
\hline Male & & $\begin{array}{c}-.110^{* * * *} \\
(.007)\end{array}$ \\
\hline Education & . & $\begin{array}{c}.119^{* * *} \\
(.007)\end{array}$ \\
\hline Evangelical Protestant & . & $\begin{array}{c}-.141^{* * *} \\
(.010)\end{array}$ \\
\hline Catholic & . & $\begin{array}{l}-.004 \\
(.012)\end{array}$ \\
\hline Other Christian & & $\begin{array}{l}-.136^{* * *} \\
(.013)\end{array}$ \\
\hline Non-Christian & & $\begin{array}{c}-.071^{* * *} \\
(.010)\end{array}$ \\
\hline Unaffiliated & . & $\begin{array}{l}.009 \\
(.013)\end{array}$ \\
\hline South & . & $\begin{array}{l}-.006 \\
(.007)\end{array}$ \\
\hline Constant & $\begin{array}{l}.346^{* * *} \\
(.007)\end{array}$ & $\begin{array}{l}.378^{* *} \\
(.007)\end{array}$ \\
\hline $\begin{array}{l}\text { Pseudo } \\
\text { Log pseudolikelihood } \\
\mathrm{N}\end{array}$ & $\begin{array}{c}.001 \\
-21196.186 \\
30,489\end{array}$ & $\begin{array}{c}.080 \\
-19502.353 \\
30,489\end{array}$ \\
\hline
\end{tabular}

Notes: Table entries are probit coefficients. Robust standard errors given in parentheses. Data are entropy weighted. ${ }^{*} p<.05^{* *} p$ $<.01^{* * *} p<.001$. 


\section{B.2 ITT Estimates for Favorability Towards Gays and Lesbians (Reigious Subsamples)}

Table 1: ITT Estimates for Favorability Towards Gays and Lesbians (Religious Subsamples)

\begin{tabular}{lcccccc}
\hline & $\begin{array}{c}\text { Mainline } \\
\text { Protestant }\end{array}$ & $\begin{array}{c}\text { Evangelical } \\
\text { Protestant }\end{array}$ & Catholic & $\begin{array}{c}\text { Other } \\
\text { Christian }\end{array}$ & $\begin{array}{c}\text { Non- } \\
\text { Christian }\end{array}$ & Unaffiliated \\
\hline Treatment & .012 & -.002 & .031 & .020 & .014 & $.043^{* *}$ \\
Party ID & $(.026)$ & $(.023)$ & $(.016)$ & $(.015)$ & $(.023)$ & $(.015)$ \\
& $-.191^{* * *}$ & $-.181^{* * *}$ & $-.134^{* * *}$ & $-.158^{* * *}$ & $-.244^{* * *}$ & $.203^{* * *}$ \\
Ideology (Conservative) & $(.038)$ & $(.038)$ & $(.018)$ & $(.017)$ & $(.027)$ & $(.022)$ \\
& $-.308^{* * *}$ & $-.227^{* * *}$ & $-.098^{* *}$ & $-.132^{* *}$ & $-.137^{* *}$ & $-.309^{* * *}$ \\
White & $(.042)$ & $(.030)$ & $(.020)$ & $(.017)$ & $(.025)$ & $(.022)$ \\
& $.127^{* *}$ & $.140^{* * *}$ & $.049^{* *}$ & $.048^{* *}$ & $.173^{* *}$ & $.100^{* * *}$ \\
Age & $(.038)$ & $(.029)$ & $(, 018)$ & $(.016)$ & $(.023)$ & $(.016)$ \\
Male & $-.124^{* * *}$ & .140 & $-.047^{* *}$ & $-.129^{* * *}$ & $-.056^{*}$ & $-.053^{* *}$ \\
Education & $(.030)$ & $(.029)$ & $(.017)$ & $(.018)$ & $(.024)$ & $(.017)$ \\
South & $-.054^{*}$ & -.099 & $-.124^{* * *}$ & $-.109^{* * *}$ & $-.128^{* * *}$ & $-.102^{* * *}$ \\
& $(.027)$ & $(.023)$ & $(.016)$ & $(.016)$ & $(.023)$ & $(.016)$ \\
\hline Constant & $.181^{* * *}$ & $.096^{* *}$ & $.086^{* * *}$ & $.086^{* * *}$ & $.124^{* *}$ & $.173^{* * *}$ \\
& $(.030)$ & $(.025)$ & $(.017)$ & $(.015)$ & $(.023)$ & $(.017)$ \\
Pseudo & -.002 & .001 & .009 & -.010 & -.025 & -.011 \\
Log pseudolikelihood & $(.026)$ & $(.022)$ & $(.017)$ & $(.014)$ & $(.023)$ & $(.096)$ \\
N & $.562^{* * *}$ & $.069^{* * *}$ & $.496^{* * *}$ & $.167^{* * *}$ & $.310^{* * *}$ & $.539^{* * *}$ \\
\hline
\end{tabular}

Notes: Table entries are probit coefficients. Robust standard errors given in parentheses. Data are entropy weighted. ${ }^{*} p<.05$ ${ }^{* *} p<.01{ }^{* * *} p<.001$. 


\section{B.3 ITT Estimates for Favorability Towards Gays and Lesbians (Parti- san Subsamples)}

Table 1: ITT Estimates for Favorability Towards Gays and Lesbians (Partisan Subsamples)

\begin{tabular}{lcccc}
\hline & Democrat & Republican & Independent & $\begin{array}{c}\text { Something } \\
\text { else }\end{array}$ \\
\hline Treatment & $.038^{* *}$ & .012 & .006 & $.069^{*}$ \\
& $(.013)$ & $(.012)$ & $(.014)$ & $(.031)$ \\
Ideology (conservative) & $-.249^{* * *}$ &.$- .097^{* * *}$ & $-.306^{* * *}$ & $-.229^{* * *}$ \\
& $(.016)$ & $(.013)$ & $(.021)$ & $(.044)$ \\
White & $.087^{* * *}$ & $.033^{*}$ & $.110^{* * *}$ & $.092^{* *}$ \\
& $(.013)$ & $(.016)$ & $(.015)$ & $(.032)$ \\
Age & $-.039^{* *}$ & $-.115^{* * *}$ & $-.070^{* * *}$ & $-.147^{* * *}$ \\
& $(.014)$ & $(.014)$ & $(.016)$ & $(.038)$ \\
Male & $-157^{* * *}$ & $-.069^{* *}$ & $-.124^{* * *}$ & $-.074^{*}$ \\
& $(.014)$ & $(.013)$ & $(.014)$ & $(.032)$ \\
Education & $.087^{* *}$ & $.088^{* * *}$ & $.144^{* * *}$ & $.190^{* * *}$ \\
& $(.014)$ & $(.013)$ & $(.015)$ & $(.036)$ \\
Evangelical Protestant & $-.160^{* * *}$ & $-.137^{* * *}$ & $-.135^{* * *}$ & -.097 \\
& $(.060)$ & $(.015)$ & $(.022)$ & $(.067)$ \\
Catholic & $-.058^{*}$ & $.048^{*}$ & -.026 & .051 \\
& $(.023)$ & $(.020)$ & $(.025)$ & $(.079)$ \\
Other Christian & $-.151^{* * *}$ & $-.105^{* * *}$ & $-.140^{* * *}$ & $-.189^{* * *}$ \\
& $(.024)$ & $(.021)$ & $(.026)$ & $(.077)$ \\
Non-Christian & $-.062^{* *}$ & $-.043^{*}$ & $-.077^{* * *}$ & $-.160^{* *}$ \\
& $(.019)$ & $(.019)$ & $(.021)$ & $(.058)$ \\
Unaffiliated & .039 & .033 & -.029 & -.056 \\
South & $(.024)$ & $(.024)$ & $(.025)$ & $(.079)$ \\
& $-.029^{*}$ & .001 & .001 & .016 \\
Constant & $(.014)$ & $(.012)$ & $(.014)$ & $(.031)$ \\
\hline Pseudo & $.566^{* * *}$ & $.153^{* * *}$ & $.392^{* * *}$ & $.184^{* * *}$ \\
Log pseudolikelihood & $(.016)$ & $(.016)$ & $(.014)$ & $(.038)$ \\
N & .066 & .036 & .058 & .069 \\
\hline Notes & -5852.5588 & -7018.2987 & -5395.1543 & -1118.6629 \\
& 10,599 & 9,856 & 8343 & 1,691 \\
\hline
\end{tabular}

Notes: Table entries are probit coefficients. Robust standard errors given in parentheses. Data are entropy weighted. ${ }^{*} p<.05^{* *} p<.01^{* * *} p<.001$. 


\section{Robustness Tests for Excludability and Compliance}

\section{C.1 Falsification Tests (Median Interview Date as Placebo Cutoff)}

Table 1: ITT Estimates for Favorability Towards Gays and Lesbians (Median Date as Placebo Cutoff)

\begin{tabular}{|c|c|c|}
\hline & Simple & With controls \\
\hline $\begin{array}{l}\text { Treatment (empirical } \\
\text { median) }\end{array}$ & $\begin{array}{l}.000 \\
(.002)\end{array}$ & $\begin{array}{c}-.001 \\
(.002)\end{array}$ \\
\hline Party ID & . & $\begin{array}{c}-.195^{* * *} \\
(.003)\end{array}$ \\
\hline Ideology (conservative) & . & $\begin{array}{c}-.210^{* * *} \\
(.003)\end{array}$ \\
\hline White & . & $\begin{array}{l}.100^{* * *} \\
(.002)\end{array}$ \\
\hline Age & . & $\begin{array}{c}-.097^{* * *} \\
(.002)\end{array}$ \\
\hline Male & . & $\begin{array}{c}-.098^{* * *} \\
(.002)\end{array}$ \\
\hline Education & . & $\begin{array}{l}.114^{* * *} \\
(.002)\end{array}$ \\
\hline Evangelical Protestant & . & $\begin{array}{c}-.147^{* * *} \\
(.003)\end{array}$ \\
\hline Catholic & . & $\begin{array}{c}-.029 * * * \\
(.004)\end{array}$ \\
\hline Other Christian & . & $\begin{array}{c}-.151^{* * *} \\
(.004)\end{array}$ \\
\hline Non-Christian & . & $\begin{array}{c}-.059 * * * \\
(.003)\end{array}$ \\
\hline Unaffiliated & . & $\begin{array}{c}.007 \\
(.004)\end{array}$ \\
\hline South & . & $\begin{array}{c}-.019 * * * \\
(.002)\end{array}$ \\
\hline Constant & $\begin{array}{l}.308^{* * *} \\
(.002)\end{array}$ & $\begin{array}{c}.345^{* * *} \\
(.002)\end{array}$ \\
\hline $\begin{array}{l}\text { Pseudo } \\
\text { Log pseudolikelihood } \\
\mathrm{N}\end{array}$ & $\begin{array}{c}.000 \\
-215361.7 \\
294,553\end{array}$ & $\begin{array}{c}.095 \\
-194820.12 \\
294,553\end{array}$ \\
\hline
\end{tabular}

Notes: Table entries are probit coefficients. Robust standard errors given in parentheses. Data are entropy weighted. ${ }^{*} p<.05$ ${ }^{* *} p<.01{ }^{* * *} p<.001$. 


\section{C.2 Placebo Tests}

Table 1: ITT Estimates for Favorability Towards Other Groups

\begin{tabular}{lc}
\hline & ITT \\
\hline Whites & -.001 \\
& $(.007)$ \\
White men & -.009 \\
& $(.007)$ \\
Blacks & .002 \\
& $(.007)$ \\
Latinos & .013 \\
& $(.007)$ \\
Asians & .010 \\
& $(.007)$ \\
Muslims & .004 \\
& $(.007)$ \\
Jews & .012 \\
& $(.007)$ \\
Evangelical Christians & .007 \\
& $(.007)$ \\
Socialists & .006 \\
& $(.007)$ \\
Labor unions & -.007 \\
& $(.007)$ \\
Democrats & -.004 \\
& $(.008)$ \\
Republicans & .006 \\
& $(.008)$ \\
\hline
\end{tabular}

Notes: Table entries represent the probit coefficient for the treatment in alternate models. Robust standard errors given in parentheses. All models control for party ID, ideology, race, age, gender, education, religion, and region. Data are entropy weighted. ${ }^{*} p<.05{ }^{* *} p$ $<.01^{* * *} p<.001$. 


\section{C.3 Results Using Heterosexual/Straight Subsample}

Table 1: ITT Estimates for Favorability Towards LGBT Individuals (Heterosexual/Straight Subsample)

\begin{tabular}{|c|c|c|}
\hline & Simple & $\begin{array}{c}\text { With } \\
\text { controls }\end{array}$ \\
\hline Treatment & $\begin{array}{l}.016^{*} \\
(.007)\end{array}$ & $\begin{array}{c}.018^{*} \\
(.008)\end{array}$ \\
\hline Party ID & . & $\begin{array}{c}-.183^{* * *} \\
(.009)\end{array}$ \\
\hline Ideology (conservative) & . & $\begin{array}{c}-.173^{* * *} \\
(.010)\end{array}$ \\
\hline White & . & $\begin{array}{c}.086^{* * *} \\
(.008)\end{array}$ \\
\hline Age & . & $\begin{array}{c}-.064^{* * *} \\
(.008)\end{array}$ \\
\hline Male & . & $\begin{array}{c}-.110 * * * \\
(.008)\end{array}$ \\
\hline Education & . & $\begin{array}{l}.128^{* * *} \\
(.008)\end{array}$ \\
\hline Evangelical Protestant & . & $\begin{array}{c}-.138^{* * *} \\
(.010)\end{array}$ \\
\hline Catholic & . & $\begin{array}{c}.005 \\
(.013)\end{array}$ \\
\hline Other Christian & . & $\begin{array}{c}-.131^{* * *} \\
(.013)\end{array}$ \\
\hline Non-Christian & . & $\begin{array}{c}-.068^{* *} \\
(.011)\end{array}$ \\
\hline Unaffiliated & . & $\begin{array}{c}.008 \\
(.014)\end{array}$ \\
\hline South & . & $\begin{array}{l}-.015 \\
(.008)\end{array}$ \\
\hline Constant & $\begin{array}{l}.300^{* * *} \\
(.007)\end{array}$ & $\begin{array}{l}.350^{* * *} \\
(.008)\end{array}$ \\
\hline Pseudo & .001 & .077 \\
\hline Log pseudolikelihood & -18860.707 & -14703.513 \\
\hline $\mathrm{N}$ & 26,801 & 26,801 \\
\hline
\end{tabular}

